\title{
Revisiting the Cupidito unit (Cupido Formation) along peritidal carbonates from northeastern Mexico
}

\section{Felipe de Jesús Torres de la Cruz ${ }^{1}$,Elizabeth Chacón-Baca ${ }^{2, *}$, Gabriel Chávez-Cabello ${ }^{2}$, and María Isabel Hernández-Ocaña ${ }^{1}$}

\author{
${ }^{1}$ Universidad Autónoma de Nuevo León, Posgrado de la Facultad de Ciencias de la Tierra, \\ Carretera a Cerro Prieto Km 8, Ex. Hacienda de Guadalupe, C.P. 67700, Linares N.L., Mexico. \\ ${ }^{2}$ Universidad Autónoma de Nuevo León, Facultad de Ciencias de la Tierra, \\ Carretera a Cerro Prieto Km 8, Ex. Hacienda de Guadalupe, C.P. 67700, Linares N.L., Mexico. \\ *baicalia2012@gmail.com
}

\begin{abstract}
Depositional episodes are readily identified along representative localities of the Lower Cretaceous Cupido platform in northeastern Mexico. The basal part of the Cupido Formation exhibits a progradational reef platform that, at the upper limit, is truncated by a sequence boundary defined by a breccia. This breccia marks the development of a peculiar sedimentary facies informally known as the Cupidito unit, a distinctive stratigraphical unit in northeastern Mexico that remained uninterpreted for decades. Through the analysis of facies, microfacies and stable isotope comparisons from representative localities (Potrero Chico, Potrero de García, La Huasteca, La Muralla and Puerto Mexico) and from other previously reported outcrops, this work describes six diagnostic features for Cupidito and an improved stratigraphic model is proposed. The depositional sequence suggests a broad flat-topped platform with a general low organic productivity and restricted conditions followed by recurrent inundations of lagoon waters. Before drowning, this carbonate platform remained under equilibrium conditions interrupted by short pulses of relative higher-temperatures ( 48.3 ${ }^{\circ} \mathrm{C}$ and $39.2^{\circ} \mathrm{C}$ ). Coral-rudist-stromatoporoid patch-reefs with inferred inter-tropical temperatures between $31.5^{\circ} \mathrm{C}$ and $32.2^{\circ} \mathrm{C}$ originated as a progradational response to the instauration of a new Sequence Boundary at the base of Cupidito.
\end{abstract}

Keywords: Peritidal carbonates; drowning platform; deposition model; sequence boundary; stratiform microbial mats; paleotemperature.

\section{RESUMEN}

Se identificaron episodios de depósito a lo largo de localidades representativas de la plataforma Cupido del Cretácico Temprano en el noreste de México. La parte basal de la Formación Cupido se compone de una facies arrecifal progradante que, en su límite superior, se trunca por un límite de secuencia identificada mediante una brecha. Esta brecha marca el desarrollo de una facies sedimentaria muy distintiva conocida como unidad Cupidito, una unidad estratigráfica reconocida en el noreste de México y que ha sido interpretada como un Tracto Sistema Transgresivo. A través del análisis de facies, microfacies y de la comparación de isótopos estables de localidades representativas (Potrero Chico, Potrero de García, La Huasteca, La Muralla y Puerto México) y de otros afloramientos previamente reportados, este trabajo describe seis características diagnósticas para la unidad Cupidito y propone un modelo de facies mejorado basado en los datos derivados de este trabajo y literatura disponible. El depósito de la Formación Cupido sugiere una plataforma amplia y plana con una productividad orgánica relativamente baja y ocasionalmente con condiciones muy restringidas, seguidas de episodios de inundaciones recurrentes de aguas de origen lagunar. Antes del episodio de ahogamiento, esta plataforma carbonatada se mantuvo en condiciones de equilibrio interrumpido por pulsos cortos de temperaturas relativamente altas (entre $48.3{ }^{\circ} \mathrm{C}$ y $39.2^{\circ} \mathrm{C}$ ). Las paleotemperaturas inferidas para los parches arrecifales de corales-rudistas-estromatopóridos intertropicales oscilan entre $31.5^{\circ} \mathrm{C} y 32.2^{\circ} \mathrm{C}$; dichos parches probablemente se originaron como una respuesta progradante a la instauración del Límite de Secuencia en la base de Cupidito.

Palabras clave: Carbonatos perimareales; plataforma ahogada; modelo de depósito; límite de secuencia; tapetes microbianos estratiformes; paleotemperatura.

\section{INTRODUCTION}

Peritidal carbonate deposits record shallow marine fluctuations on supratidal, intertidal and subtidal facies that are abundant and ubiquitous through the fossil record worldwide (Wright, 1984), but especially abundant during the Cretaceous (Joachimski, 1994; Ferreri et al., 2004; Strasser, 2007; D' Argenio et al., 2008; Sena, 2014). Along the Sierra Madre Oriental in northeastern Mexico, the Cupido Formation stands out as the most prominent example of peritidal carbonates, covering vast areas in the states of Nuevo Leon, Coahuila, Zacatecas and Durango. If not eroded, the Cupido Formation crowns the uppermost part of northern anticlines from the Sierra Madre Oriental (Padilla y Sánchez, 1985). The Lower Cretaceous Cupido Formation was deposited as a low-amplitude carbonate platform that repeatedly exposed peritidal carbonates (Conklin and Moore, 1977; Wilson and Pialli, 1977; Lehmann et al., 1998, Lehmann et al., 2000). This unit started its accumulation over the Taraises Formation during 
the Hauterivian (Zwanzinger, 1978; Goldhammer and Johnson, 2001; Humphrey and Díaz, 2003; Murillo-Muñetón and Dorobek, 2003; Ángeles-Villeda et al., 2005) and its deposition continued throughout the Barremian (Lehmann et al., 1998; Wilson, 1999). The upper limit of the Cupido Formation is marked by the contact with the Aptian La Peña Formation, whose type locality is situated at the Mimbre canyon in Parras de la Fuente, Coahuila (Imlay, 1937).
Informally known as the Cupido Limestone in the first descriptions, the Cupido Formation was originally reported as a non-fossiliferous unit (Imlay, 1937), but years later it was recognized and described by Humphrey (1949) as a formation, in Sierra de Los Muertos, Nuevo Leon, and as a fossil-poor deposit (Figure 1). After thirty years the Cupido Formation became acepted as the Cupido Reef (Zwanzinger, 1978). At present, the Cupido Formation is widely known as a fossiliferous

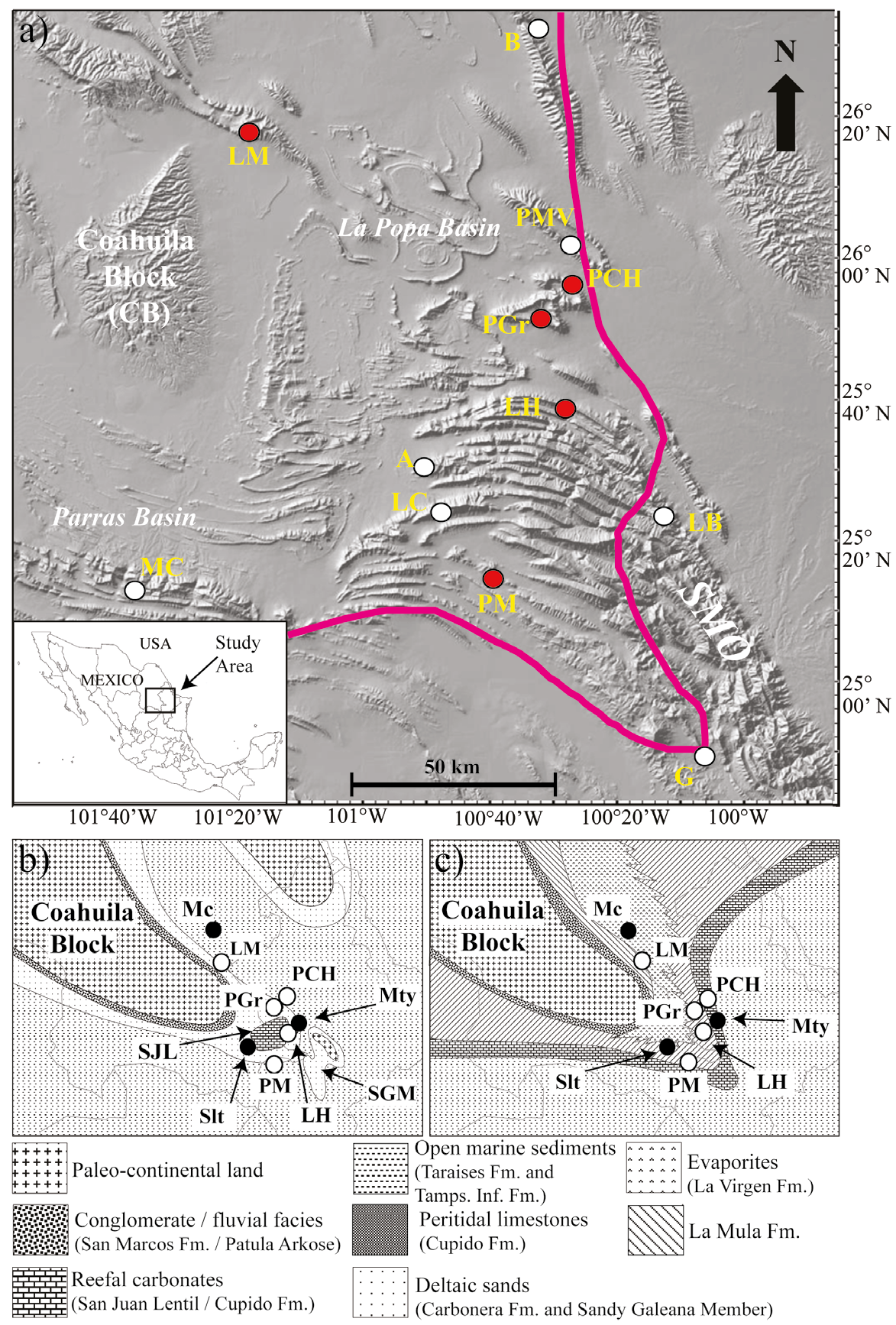

Figure 1. (a) Regional map showing representative outcrops of the Cupido Formation (white bullets), and analyzed outcrops in this work (red bullets). Sierra de Arteaga (A), Galeana (G), Potrero de García (PGr), Puerto México (PM), La Muralla (LM), Potrero Chico (PCH), Potrero Minas Viejas (PMV), Bustamante (B), La Boca (LB), Los Chorros (LC), La Huasteca (LH), and the Mimbre Canyon (MC). Disposition of the Cretaceous platform edge is represented by the pink line (After Wilson, 1999). (b-c) Paleogeographic non-palinspatic reconstruction of the Cupido Formation with localities of the study area with white bullets. (b) Upper Jurassic-Lower Cretaceous and (c) Barremian-lower Aptian. (Mc) Monclova; Monterrey (Mty); Saltillo (Slt); Sandy Galeana Member (SGM); San Juan Lentil (SJL); (Modified after Eguiluz de Antuñano, 1990; Lehmann et al., 1998; Goldhammer and Johnson, 2001; Ocampo-Díaz et al., 2008). Acronyms of localities will be used in the following figures. 
unit, that has been interpreted as a patch reef complex platform (Conklin and Moore, 1977; Wilson and Pialli, 1977). The Cupido Formation represents part of an extensive carbonate platform system (Murillo-Muñetón and Dorobek, 2003), that originated as an extensive coastal lagoon with peritidal cyclic carbonates between the Coahuila Block basement and a patch reef belt and a barrier shoal margin (Conklin and Moore, 1977; Wilson and Pialli, 1977; Selvius and Wilson, 1985; Goldhammer et al., 1991; Lehmann et al., 1998). Eventually, the Cupido Formation developed as a reef-rimed carbonate platform composed of corals, stromatoporoids, sponges, rudists, dasycladacean algae and benthic foraminifera (Wilson, 1999). The development of the Cupido Formation occurred in the interior platform and probably was controlled by Milankovitch-driven climatic changes (Lehmann et al., 1998). Most authors consider that the Cupido Carbonate System (including the inner and margin platform, and open marine facies) developed as prograding cycles, ranging from the Late Hauterivian through the Aptian (Humphrey and Díaz, 2003; Zwanziger, 1978; Michalzik, 1988; Guzmán-García, 1991; McFarlan and Menes, 1991; Goldhammer, 1999; Hernández-Trejo, 2003; Murillo-Muñetón and Dorobek, 2003; Eguiluz de Antuñano, 2011). This age has also been confirmed by the presence of Nannoconus bermudez Bronimann, Nannoconus steinmann Keampther and Nannoconus elongatus Bronnimann (Padilla y Sánchez, 1978). The Cupido Formation shows a great variation in thickness (Wilson and Pialli, 1977), including variations of more than $500 \mathrm{~m}$ (Conklin and Moore, 1977), between 230 to $800 \mathrm{~m}$ in thickness (Tardy, 1973) or even larger variations (Torres de la Cruz et al., 2018).

The lower part of the Cupido Formation consists of medium darkgrey shale-limestones with stylolites and fractures filled by calcite. The medium part consists of medium to coarse gray mudstone-wackestones intercalated by thin shale layers with sporadic black chert lenses and iron nodules. In contrast, the upper part of the Cupido Formation is characterized by shallow thin-bedded peritidal and subtidal deposits from inner and middle shelf-deposits including laminated mudstones alternating with bioturbation horizons and burrowed skeletal packstones. Precisely within this unit, informally known as Cupidito, it is possible to observe an erosive surface that has produced solution collapse breccias (Conklin and Moore, 1977; Wilson and Pialli, 1977).

Though Cupidito is a well-represented unit in northern Mexico (Conklin and Moore, 1977; Fischer and Jackson, 1999; Lehmann et al., 1999), a long-standing debate exists over whether Cupidito should be interpreted as an informal unit, as a stratigraphic stage, as a hiatus in deposition, or merely as a sedimentary breccia (Figure 1). Over the years the study of the Cupido Formation and the recognition of Cupidito unit (Table 1) has been informally accepted in all field-campaigns (fieldwork) and regional reports (Amsbury, 2000; Lehmann et al., 2000; Torres de la Cruz, 2011; Torres de la Cruz, 2014; Gómez-Mancha, 2016).

This work aims to document the Cupidito stratigraphical relationships, lithofacies, microfacies and geochemical characteristics useful for paleogeographic reconstructions within the regional context. Besides, since the Cupidito unit precedes the drowning of the Cupido platform, a detailed characterization is essential. Finally, this facial characterization will add new elements to assess the oil potential of the Cupido Formation, substantiated by the potential results derived from the Totonaca-1 wellbore near to Nuevo Laredo, Mexico (Echanove, 1986).

\section{GEOTECTONIC BACKGROUND}

The complete opening of the Gulf of Mexico was marked by rifting and drifting processes during the Jurassic (Goldhammer et al., 1991), and by the closure of the northeastern passive margin at a later cooling stage (Goldhammer et al., 1991; Goldhammer and Johnson, 2001). New accommodation space became available and eventually was occupied by seawater and evaporites from the Minas Viejas Formation. These evaporitic deposits were formed during the same episode and also generated the salt deposits of Louann in Texas and the Campeche Salt Basin (Pindell, 1985). At the same time, these deposits evidence the first Jurassic marine incursion in this region (Kroeger and Stinnesbeck, 2003). Massive limestones from the Zuloaga Formation developed under shallow epicontinental seas, presumably less than $100 \mathrm{~m}$ deep

Table 1. Previous works on the age of the Cupido Formation.

\begin{tabular}{|c|c|c|c|c|}
\hline Locality & Bottom & Top & Based on & Reference \\
\hline Saltillo area & Barremian & lower Aptian & Chofatella, Pseudocyclatnmina. & Wilson and Pialli, 1977 \\
\hline Vaquerias 2 well bore (Burgos basin) & $* * *$ & $\begin{array}{l}\text { Barremian to lower } \\
\text { Aptian }\end{array}$ & $\begin{array}{l}\text { Nannoconus truitti, N. minutus, N. steinmanni, } \\
\text { N. elongatus, N. kamptneri, N. wassalli, N. colomi, } \\
\text { Globochaete alpina and Microcalamoides diversus. }\end{array}$ & Cantú-Chapa, 1989 \\
\hline Sierra de Parras & $* * *$ & $\begin{array}{l}\text { upper Barremian to } \\
\text { lower Aptian }\end{array}$ & $\begin{array}{l}\text { Saynoceras mexicanum, Parancyloceras sp., } \\
\text { Ancyloceras sp. and Hemierioceras sp. }\end{array}$ & Humphrey and Díaz, 2003 \\
\hline Symon (Durango) & lower Barremian & $* * *$ & Pulchellia and Pseudohaploceras. & Humphrey and Díaz, 2003 \\
\hline Bustamante canyon (Nuevo León) & Hauterivian & $* * *$ & $\begin{array}{l}\text { Association of Vercosella winteri and } \\
\text { Salpingoporella cf. annulata. }\end{array}$ & $\begin{array}{l}\text { Murillo-Muñetón and } \\
\text { Dorobek, } 2003\end{array}$ \\
\hline La Boca canyon (Nuevo León) & upper Hauterivian & lower Aptian & $\begin{array}{l}\text { Conorotalites, Coskinolenoides and Caucasella } \\
\text { hauterivica. }\end{array}$ & Ángeles-Villeda et al., 2005 \\
\hline Francisco Zarco dam (Durango) & $* * *$ & lower Aptian & Palorbitolina cf. lenticularis. & Núñez-Useche et al., 2012 \\
\hline Puerto Mexico (Nuevo León) & $* * *$ & $\begin{array}{l}\text { lower Aptian-upper } \\
\text { Aptian }\end{array}$ & $\begin{array}{l}\text { Toucasia, Pseudotoucasia, Amphitriscoellus, } \\
\text { Offneria, Douvillelia. }\end{array}$ & Torres de la Cruz et al., 2018 \\
\hline
\end{tabular}


(Pessagno and Martin, 2003). The Zuloaga Formation has been considered as a homoclinal carbonate ramp (Eguiluz de Antuñano et al., 2000) covered by La Casita Formation (Upper Jurassic) and derived from a major siliciclastic sedimentary influx, mainly from the Coahuila Block source area (Fortunato and Ward, 1982). Except for the Coahuila Block, most of the structural highs remained underwater during the Upper Jurassic-Lower Cretaceous times (Goldhammer, 1999). During the Barremian and Albian, carbonate platforms (Figure 1) reached their maximal extension around the coast of the Gulf of Mexico (Zwanziger, 1978; Wilson y Ward, 1993; Lehmann et al., 1998; Wilson, 1999) and accumulated a thickness of approximately $2000 \mathrm{~m}$; for instance, in the Cupido and Aurora formations. The Tethys aperture inside the proto-Gulf of Mexico during the Cretaceous also influenced changes in the sea level, causing a shift in the coastline toward the north during the Barremian and lower Aptian (Chávez-Cabello et al., 2005). The Coahuila Block remained as an island where the Cupido Formation eventually deposited as a prograding carbonate platform with frontal reefs to the east (Nuñez-Useche et al., 2014). From the Berriasian throughout the Upper Hauterivian, fluvial and clastic sediments from San Marcos and La Mula formations, respectively, covered the northeastern continental margin of the Coahuila Block. Similar deposits also filled the southern edge of the Burro Peyotes Island (Jones et al., 1984; Goldhammer and Johnson, 2001). The eastern front of the Coahuila Block, the Carbonera and La Casita formations integrated into a deltaic system known as Saltillo Delta, which extended from the Coahuila Block to Saltillo-Monterrey (Ocampo-Díaz, 2011). A coral-rich carbonate lentil (San Juan Lentil) developed over a high relief inherited from this deltaic system at the lower part of the Taraises Formation (Zell et al., 2016). This lentil reflects a transgression, probably induced by oligotrophic conditions and the lack of a continuous sediment supply from the Coahuila Block. At the same time, the Sandy Galeana Member of the Taraises Formation developed with a depocenter in Galeana (Ocampo-Díaz et al., 2008); both deltaic systems line up in a NW-SE orientation. The Cupido sequence was deposited over the homocline ramp of the Taraises Formation (Murillo-Muñetón and Dorobek, 2003). The fluvial-siliciclastic-carbonate succession deposited from the Berriasian to the Hauterivian was covered by a Transgressive System Tract, marked by the upper Taraises Formation (Eguiluz de Antuñano, 1990); this Maximum Flooding Surface was also acknowledged by Lehmann et al. (2000), precisely where the Cupido Formation originated. The Tamaulipas Inferior Formation developed simultaneously with the Cupido Formation deposition along neritic and infra-neritic environments away from the coast (Humphrey and Díaz, 2003).

While a consensus exists for the upper age of the Cupido Formation, its basal age limit shows variations and remains poorly defined and highly depends on the regional geology (Table 1). In the type locality, Sierra de Parras, the basal age for Cupido has been assigned to Late Hauterivian (Imlay, 1937; Humphrey and Díaz, 2003). In Bustamante canyon, Murillo-Muñetón and Dorobek (2003) assigned an Upper Hauterivian to Barremian as the most probable age for the base of Cupido. According to the stratigraphic record of Conorotalites, Coskinolenoides and Caucasella hauterivica, a Late Hauterivian age was assigned for lower Cupido in La Boca canyon (Ángeles-Villeda et al., 2005). Based on the occurrence of the benthic foraminifera Choffatella decipiens, the Cupido Formation corresponds to the Barremian (Wilson, 1999). In the area of Saltillo, Wilson and Pialli (1977) added Choffatella as a stratigraphic marker from the early Cupido Formation as well as in Arteaga canyon, where these foraminifera were reported from the Lower Acatita Formation and the upper Las Uvas Formation of the Coahuila Block (Lehmann et al., 1999); both formations correlate laterally with Cupido/Cupidito and La Peña Formation. Choffatella decipiens was reported at the top of Cupido Formation in Sierra del
Rosario in Durango (Barragan-Manzo and Díaz-Otero, 2004); however, this work did not include neither the mid nor the lower part of Cupido Formation. Choffatella decipiens was also reported from La Virgen Formation in Potrero de Menchaca, in the northeastern Coahuila Block (Gutiérrez-Alejandro et al., 2017). Choffatella decipiens is a worldwide foraminifera species that dates back to the Barremian, although some suggest a Hauterivian age (González-Fernández et al., 2014; Guerrero-Moreno, 2018).

\section{METHODS}

This study reports seven localities distributed in Nuevo Leon (NL) (numbered with their acronym to simplify regional names, as indicated in Figure 1a). Petrographic analyses included 165 samples; observations were made under a Nikon Microscope with conventional transmitted polarized light. The petrographic analysis was based on the classification guidelines given by Dunham (1962). Samples for stable isotopes $\left(\delta^{18} \mathrm{O}\right.$ and $\left.\delta^{13} \mathrm{C}\right)$ were analyzed at the Analytical Laboratory for Paleoclimate Studies (ALPS) in the Jackson School of Geosciences, University of Texas at Austin. Samples were acidified under vacuum at $70{ }^{\circ} \mathrm{C}$ with $100 \%$ phosphoric acid. Distilled $\mathrm{CO}_{2}$ was analyzed on a Thermo MAT253 with Kiel IV carbonate preparation device followed by $\mathrm{CO}_{2}$ determination. Isotopic measurements were calibrated using the reference NBS19 and an internal marble standard (ESTREMOZ) with average values for $\delta^{18} \mathrm{O}=-5.95 \%$ and for $\delta^{13} \mathrm{C}=1.63$ according to Ostermann and Goodkin (2012), with analytical errors for $\delta^{18} \mathrm{O} \pm 0.08 \%$ and for $\delta^{13} \mathrm{C} \pm 0.04 \%$.

The resulting $\delta^{13} \mathrm{C}$ and $\delta^{18} \mathrm{O}$ values were plotted in a comparative diagram following the data compiled by Hudson (1977), Nelson and Smith (1996) and Moldovanyi and Lohmann (1984). In order to obtain paleotemperature values comparable to similar works reported in literature, Equation 1 from Erez and Luz (1983) and Equation 2 from Anderson and Arthur (1983) were applied in 12 samples. According to Moldovanyi and Lohmann (1984), proposed isotopic studies of the Cupido Formation and in its corresponding formation in Texas (the Sligo Formation) the introduction of a correction factor is needed for paleotemperature estimations. Therefore, our estimations included a $-2.0 \%$ (denoted as $\delta \mathrm{w}$ ), as the required correction factor from the above equations, that was applied to the $\delta^{18} O$ values derived from the Cupido Formation, since this variable changes depending on the age and carbonate type analyzed (Moldovanyi and Lohmann, 1984). Finally, the isotopic values derived from this work were compared with other peritidal carbonates from Cretaceous platforms reported elsewhere in the literature.

For temperature determination, the following equations were used:

$$
\begin{gathered}
t\left({ }^{\circ} \mathrm{C}\right)=17.0-4.52\left(\delta^{18} O c-\delta^{18} O w\right)+0.03\left(\delta^{18} O c-\delta^{18} O w\right)^{2} \\
t\left({ }^{\circ} \mathrm{C}\right)=16.0-4.14(\delta c-\delta w)+0.13(\delta c-\delta w)^{2}
\end{gathered}
$$

Where $t\left({ }^{\circ} \mathrm{C}\right)$ is the estimated temperature, and $\delta^{18} \mathrm{Oc}$ and $\delta^{18} \mathrm{O} w$ are the oxygen isotopic compositions of the carbonate and seawater, respectively; $\delta c$ is the sample value of $\delta^{18} O$ and $\delta w$ is the $\delta^{18} O$ value of ambient seawater. For petrographic analysis, thin sections were prepared and classified following Dunham's classification (Dunham 1962), and Folk's classification $(1959,1962)$ when necessary.

\section{RESULTS}

The most representative outcrops of Cupido (Figure 1a) occur in La Huasteca (LH) and in Potrero de García (PGr), where they are 
accessible, show well-defined lower and upper limits, and most facies occur within a well-exposed continuum. An ideal stratigraphic column from the Cupido Formation (Figure 2) integrates the following localities: La Huasteca ( $\mathrm{LH})$, Potrero Chico (PCH), Potrero de García (PGr), and Puerto Mexico (PM). The facies of the Cupido Formation includes mudstones with microfossils (mainly calcareous algae, miliolids and textularids foraminifera) and reef carbonates with packestone-grainstone rudist shells, gastropods, stromatoporoids, and dasycladaceans interbedded with bioturbation horizons alternating with stratiform microbial mats. The basal and middle sections of Cupido contrast in thickness, frequency and microfacies with the upper section, the Cupidito unit.

\section{The basal and middle section of Cupido}

The $580 \mathrm{~m}$-longitudinal section in LH comprises three major lithofacies that, from the base (number 1 in Figure 3) to the top (number 2 in Figure 3), include the Taraises-Cupido contact throughout the upper contact with the La Peña Formation (Figure 3). The basal 60

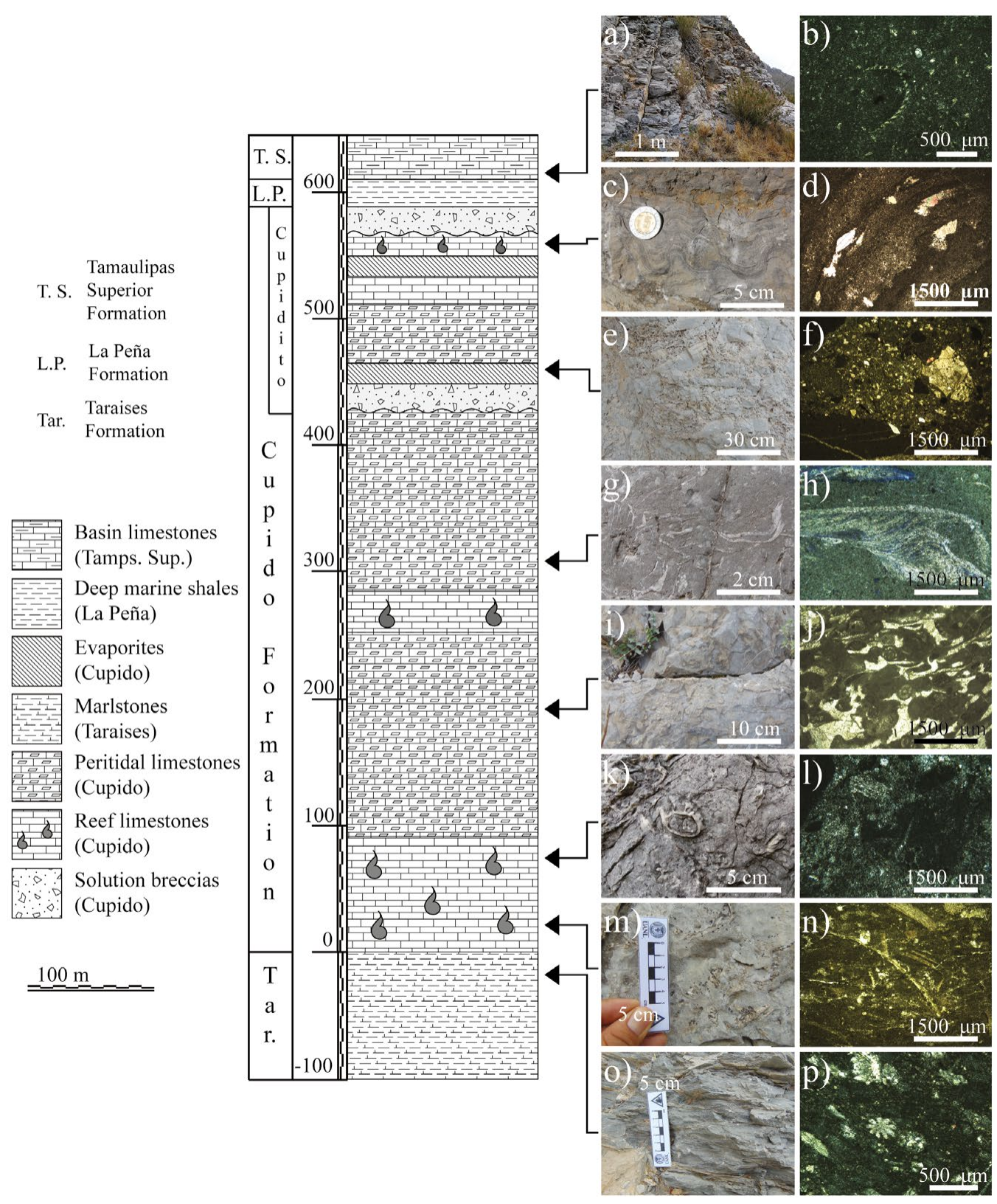

Figure 2. Idealized stratigraphic column and major macro and microscopic characteristics from the following Cupido Formation oucrops: LH, PCH, PGr, PM and LM. (a) Limestone from the Tamaulipas Superior Formation at LM. (b) Microcalamoides (Applinocrinus) of the Tamaulipas Superior Formation at LH (sample TSLH-01). (c) Domal stromatolites at the upper Cupido Formation in PGr. (d) Alternation between micritic (dark) and microsparitic (light) stromatolitic lamination and evaporitic crystals at PGr (CPG-14). (e) Solution breccia at the base of the Cupidito Member in LH. (f) Lithoclasts on a cripstocrystalline matrix LH (FSB-03). (g) Chondrodonta shells at PCH. (h) Microstructure of a Chondrodonta shell fragment, at PCH (PCH-04). (i) Bioturbation in PM. (j) Microfossils infilling burrows at LH (FSCP06). (k) Rudists and shell fragments on a granular matrix (calcarenite) at PCH. (l) Intraclasts with miliolids on a sparitic cement (PCH-E). (m) Stromatoporoids on the basal reef body of LH. (n) Packstone with shell fragments in a chemically-compacted fabric from the lower reef facies at LH (FSCP-01). (o) Marlstone with pencil cleavage in the Taraises Formation at LH. (p) Echinoid spine on a mudstone from the Taraises Formation at LH (TALH-02). 




Figure 3. Panoramic view of the most representative Cupido Formation outcrop in northeastern Mexico: the south limb of Los Muertos anticline in the LH, Nuevo León (Arrow points to a person as scale). The curly bracket signals the bottom of Cupido (1) and the sequence to the top at the contact with La Peña (2). The dotted line frames the basal collapse breccia (bcb), and upper collapse breccia (ucb) of the Cupidito unit.

m-section occurs as massive competent dark (dolomitized) to light grey reef limestones; the LH and PGr localities expose a concordant transition between the lower limit of the Cupido and the Taraises formations, where marls, with pencil or acicular cleavage, and argillaceous limestones dominate; this gradual transition from Taraises to Cupido is visible at the microtextural level too (Figure 4a). A prominent breccia containing rock fragments with rudists is exposed in the Cupido basal strata from PCH (Figure $4 \mathrm{~b}$ ), in association with clearly recrystallized deformed fragments generated by ductile deformation (Figure 4c) and with dolomitic crystals (Figure $4 \mathrm{~d}$ ). Reef facies are common in this basal breccia; for instance, in PGr, the breccia is covered by $\sim 100$ $\mathrm{m}$-thick-massive rudstone-limestones with miliolids and green algae (Figures $4 \mathrm{e}-4 \mathrm{f})$. In $\mathrm{LH}$, the basal reef facies are characterized by a massive rudist-stromatoporoid complex (Figures $4 \mathrm{~g}-4 \mathrm{~h}$ ).

The basal section of Cupido is followed by a mid-section of peritidal carbonates, which is the thickest section of the Cupido Formation, as evidenced in Figure 3. Approximately $420 \mathrm{~m}$ of peritidal carbonates, composed of cyclically-arranged horizons with light to dark graymedium-bedded bioturbation, alternate with stratiform algal mats (Figures 5a-5d); massive and competent gray dolomitic beds are frequent. This succession consists of wackestones, packestones and grainstones of miliolids, pellets and calcareous green algae remains as burrows infill (Figures 5e-5f). The mid-section ends abruptly with slope breccias followed by thin successive reef limestones that mark a sedimentary package known as the Cupidito unit.

\section{The Cupidito unit}

The uppermost $120 \mathrm{~m}$ of the Cupido Formation are framed by collapse breccias that mark the so-called Cupidito unit (Figures 6a-6c); these breccias are characteristically composed of recrystallized fragments of the Chondrodonta clam and minor minerals such as hematite, glauconite and clays (Figures $6 \mathrm{~d}-6 \mathrm{f}$ ). The Cupidito unit is a sedimentary package composed of medium-to-thin-bedded horizons of bioturbation alternating with light-coloured-stratiform mats that grade into domal and parabolic stromatolites (Figures 7a, 7c, 7e and $7 \mathrm{i})$. The presence of stromatolites with complex morphologies in Cupidito contrast with the basal and middle sections of Cupido. The mat microstructure is dominated by irregular and wrinkle lamination, either with smooth or granular textures (Figure 7b); dark laminations are thinner and more variable than light laminations; large fenestrae may develop vugular porosity filled with sparitic cements (Figure 7d). The most characteristic facies are relatively thin-mats and bioturbation cycles at the exposed localities of Cupidito in northeastern Mexico (Figures $7 \mathrm{f}-7 \mathrm{~g}$ ). The bioturbated horizons are mainly identified as firmgrounds with burrows networks (Figures 7i-7j), whose internal infill consists of pellets, miliolids and calcareous green algae within a sparitic matrix (Figures 6f). Chert nodules are well-developed in Cupidito (Figure 7f). These distinctive cyclic horizons extend from 400 to $600 \mathrm{~m}$ up to La Peña Formation. In some localities these peritidal carbonates may be truncated by 2-3 m-thick evaporitic horizons, while in other localities Cupidito may be represented by more than one collapse breccia.

\section{Pre-drowning deposits}

Despite the lithological contrast between Cupido and La Peña formations, the documentation of the Cupido drowning sequence has been especially complicated because of their geomorphology and restricted access. The use of satellite images was a valuable tool to identify the contact between Cupido and La Peña (Figures 8a-8c). While Cupido tends to form high and steep escarpments (Figure 8c), the erosion of La Peña Formation produces saddle-sediments that remain hidden; this topography severely limits sampling. Instead, the observation of vegetation differences among geological formations is practical and confident to some extend; the vegetal coverage in Cupido clearly differs from the abundant leafy trees oriented in parallel to the bedding of the La Peña Formation. Furthermore, the occurrence of Microcalamoides is an indirect indication of the transition to the Tamaulipas Superior Formation, and therefore is a useful mark especially when the La Peña Formation is not exposed.

\section{Carbon and Oxygen Isotopes}

The isotopic values and estimated paleotemperatures obtained from the PM, LH, and PGr localities are shown in Table 2. The isotopic values are similar among localities, with a higher variation in $\delta^{13} C$ than 

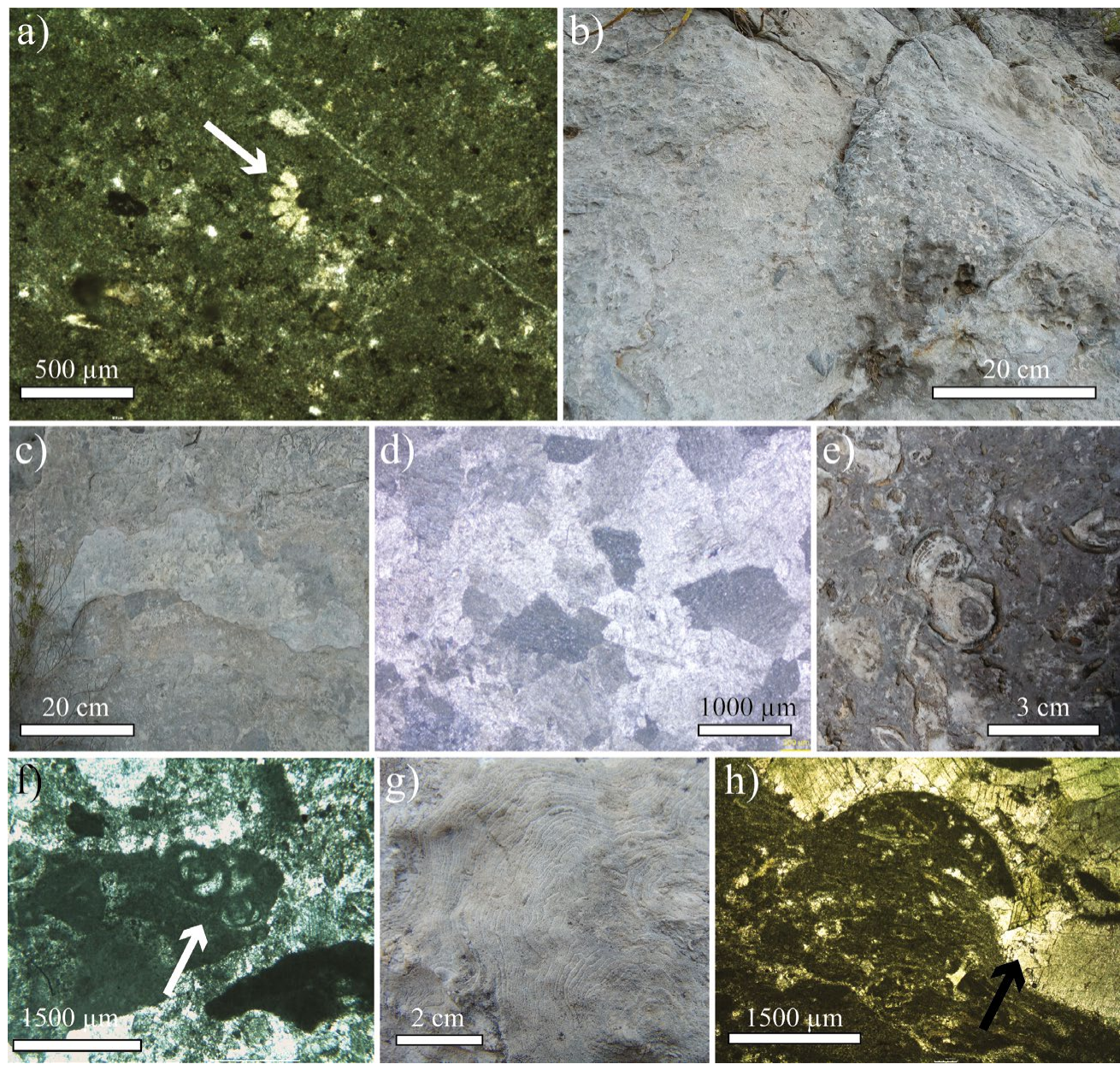

Figure 4. Basal facies of the Cupido Formation. (a) Fragment of an echinoid spine from the Taraises Formation (arrow). (b) Limestone clast with abundant rudists. (c) Ductile deformation on a limestone fragment. (d) Micrograph of well-packed dolomite on the basal breccia at PCH. (e) Toucasia shells from reef facies at PCH. (f) Intraclast with benthic foraminifera (arrow) at the upper part of the PCH reef facies. (g) Detail of Stromatoporoid from the LH lower reef facies. (h) Microphotography of a recrystallized rudist shell (arrow) within a chaotic wackestone matrix.

in $\delta^{18} \mathrm{O}$. The estimated paleotemperature renders a range between 23.8 and $48.3{ }^{\circ} \mathrm{C}$ (Figure 9), after the applied equations described in the Methods chapter.

A comparison of stable carbon and oxygen isotopes from diverse Cretaceous localities is shown in Table 3, which includes Early Cretaceous Marine Carbonate Baseline from Moldovanyi and Lohmann (1984); a factor correction of 4 has been added to the $\delta^{13} C$ values and a -2 correction factor has been subtracted from the $\delta^{18} O$ values.

\section{Cupidito as a sequence boundary}

As evidenced in the previous figures from $\mathrm{LH}$ and $\mathrm{PCH}$ (Figures 3-7), a sequence boundary is characterized by several collapse breccias, whose erosive surfaces overlie the characteristic gray stratiform microbial mats. At the microscopical level, the breccia shows calcitic fragments with pression-solution evidences preserved within an unfossiliferous matrix that contains dolomite crystals and subrounded micritized grains of varying size. The integration of previous data into a theoretical cross section from the regional geology during the Hauterivian-Albian results in the scheme showed in Figure 10, that illustrates the Cupidito unit included as initial hiatus during the Cupido evolution. The Cupidito unit lies between the sequence boundary and La Peña Formation.

\section{The stratigraphic correlation of Cupidito}

The Maximum Flooding Surface (MFS) from La Peña Formation has been used as DATUM (base level of stratigraphic columns correlation) in the stratigraphic correlation of Figure 11. The basal Cupido Formation is characterized by a reef biota in most revised localities, except in $\mathrm{PCH}$, where the base is strongly narrowed. The lowermost Cupido strata are marked by a $3-5 \mathrm{~m}$ breccia (Figures $4 \mathrm{~b}-4 \mathrm{~d}$ ), and capped by more than 100 meters of massive rudstone reef facies (Figure 4e); in contrast, Cupido is approximately $440 \mathrm{~m}$-thick in PCH. Our observations suggest that peritidal facies dominate in most of the observed vertical profiles, and show a clear trend to be thicker toward the basin. Except for one locality (PM), the Cupidito unit is recognized in all Cupido localities: In PCH starts at $370 \mathrm{~m}$ from the base of Cupido; in PGr the lower limit of Cupidito is hidden by recent sediments, nevertheless, it has an estimated thickness of $120 \mathrm{~m}$; in LH, Cupidito has $130 \mathrm{~m}$ of thickness and in LM, it has $110 \mathrm{~m}$. The basal PM reef facies consist of several 1-2 m-horizons spaced by several meters, but not fully exposed; using a parallel locality (as clearly explained in Torres de la Cruz et al., 2018) the estimation of Cupido thickness in PM was approximately $680 \mathrm{~m}$. Lastly, the localities that expose the majority of Cupidito diagnostic facies are PG and LH. Likewise, the reef facies average $40 \mathrm{~m}$ and $60 \mathrm{~m}$ in the PG and LH localities, respectively. A 

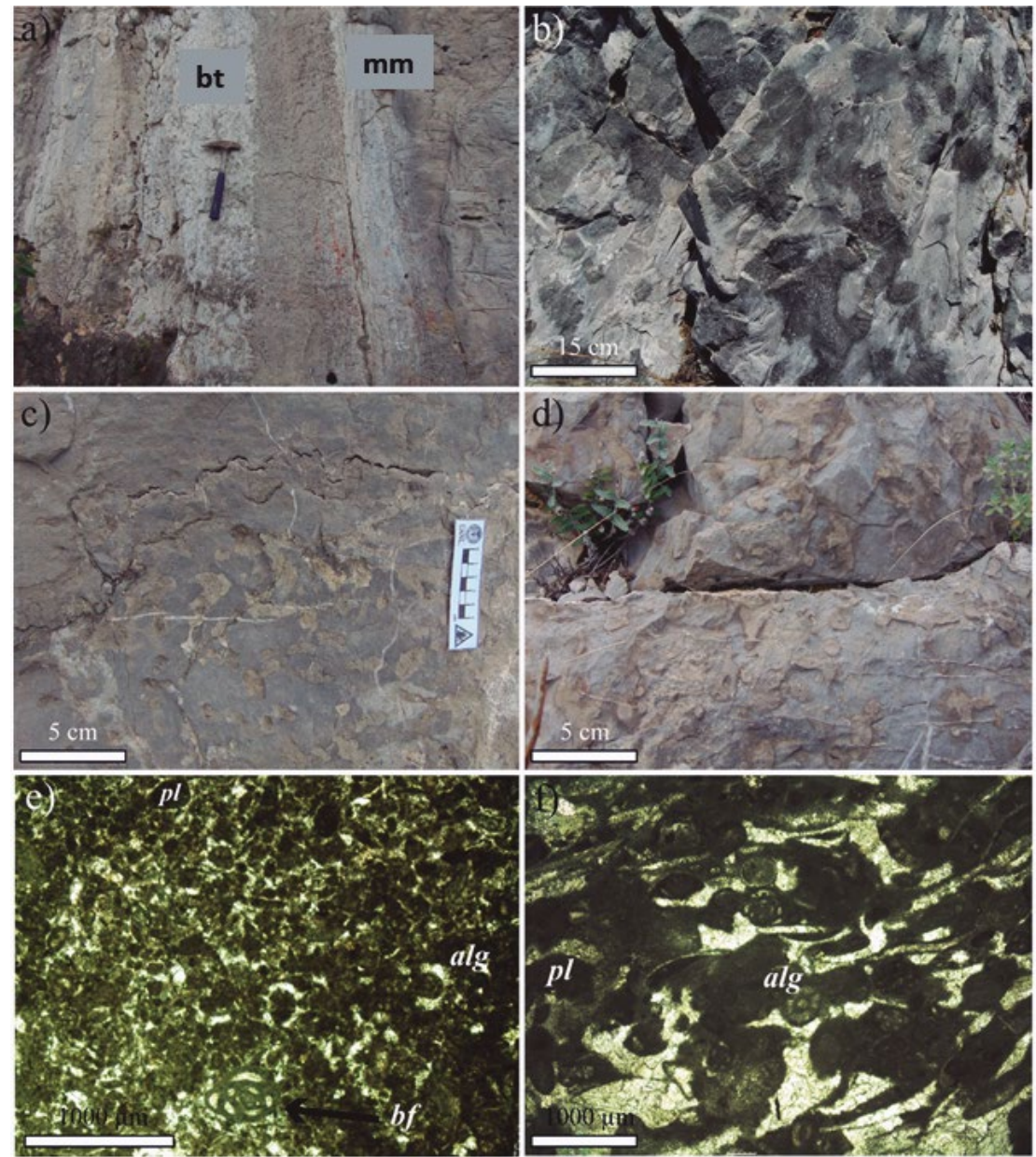

Figure 5. Middle section of Cupido. (a) Alternating facies of stratiform microbial mats (mm) and bioturbation horizons (bt) in LH. (b) Upward size increase of burrows in LH. (c) Coarse infill inside burrows in LC. (d) The shape and size burrows change along the stratigraphic column, PM. (e - f) Grainstone of miliolids, pelloids and calcareous green algae; (bf) benthic foraminifera; ( $p l$ ) pelloid; (alg) green algae.

constant feature in all localities is the regularity of La Peña Formation, which is a well-characterized regional seal (Figure 8 and 11).

\section{DISCUSSION}

A Transgressive System Tract (TST) lies within a Sequence Boundary (SB) at the uppermost part of the Cupido lithofacies. Between Cupidito and La Peña Formation, there is a well-characterized transition that corresponds to a Maximum Flooding Surface (MFS) (Eguiluz de Antuñano, 2001), recognized by deep-basin deposits that records the platform drowning during the "Gargas event" (Núñez-Useche et al., 2014). The geological and facies analysis of the revised localities confirms the general interpretation of Cupidito as transgressive-retrogradant carbonate succession deposited before platform drowning. In this case, the Transgressive System Tract would be Cupidito and La Peña Formation would be the Maximum Flooding Surface.

\section{Diagnostic facies in Cupidito}

The general geological and sedimentary structures in the exposed outcrops of Cupidito share distinctive characteristics with differences due to regional geological variations. A summary of diagnostic lithofacies and microfacies from the analyzed outcrops from Cupidito are:
(1) The presence of limit-collapse-breccias occurring either at the lower and/or upper contacts with Cupidito and La Peña formations, respectively, as observed in LH (Figures 7a and 7c); (2) Well-developed and thin-bedded stratiform microbial mats that frequently grade into stromatolitic with domal or parabolic shapes (Figures $7 \mathrm{~b}$ and $7 \mathrm{~d}$ ); (3) Chondrodonta, ostreiform shells are common across the thickness of the Cupido Formation, but are characteristically abundant in Cupidito (Figures 7g-7h). (4) The occurrence of Toucasia shells as a monotypic population in $20 \mathrm{~cm}$-thick-beds. (5) Chert nodules occur at the uppermost part of Cupidito; some outcrops such as LM and $\mathrm{PCH}$ expose distinctive black nodules (Figure 7f); (6) Although calcitic nodules are widely extended through the middle-upper section of the Cupido Formation, they are especially common in all localities as typical Cupidito diagenetic features (Figure 7k). Although Cupidito is recognizable in most localities, not all of its distinctive features are concurrently exposed. Though sedimentary facies are present in most localities of Cupidito outcrops, the most representative Cupidito locality is La Huasteca ( $\mathrm{LH})$, proposed here as the type locality for Cupidito. Additionally, this locality offers a well-preserved sub-vertical stratification, workable dimensions and easy access to document a complete stratigraphic section.

Other additional characteristics as the occurrence of cherty nodules are recognizable at Potrero Chico and La Muralla; however, this could 

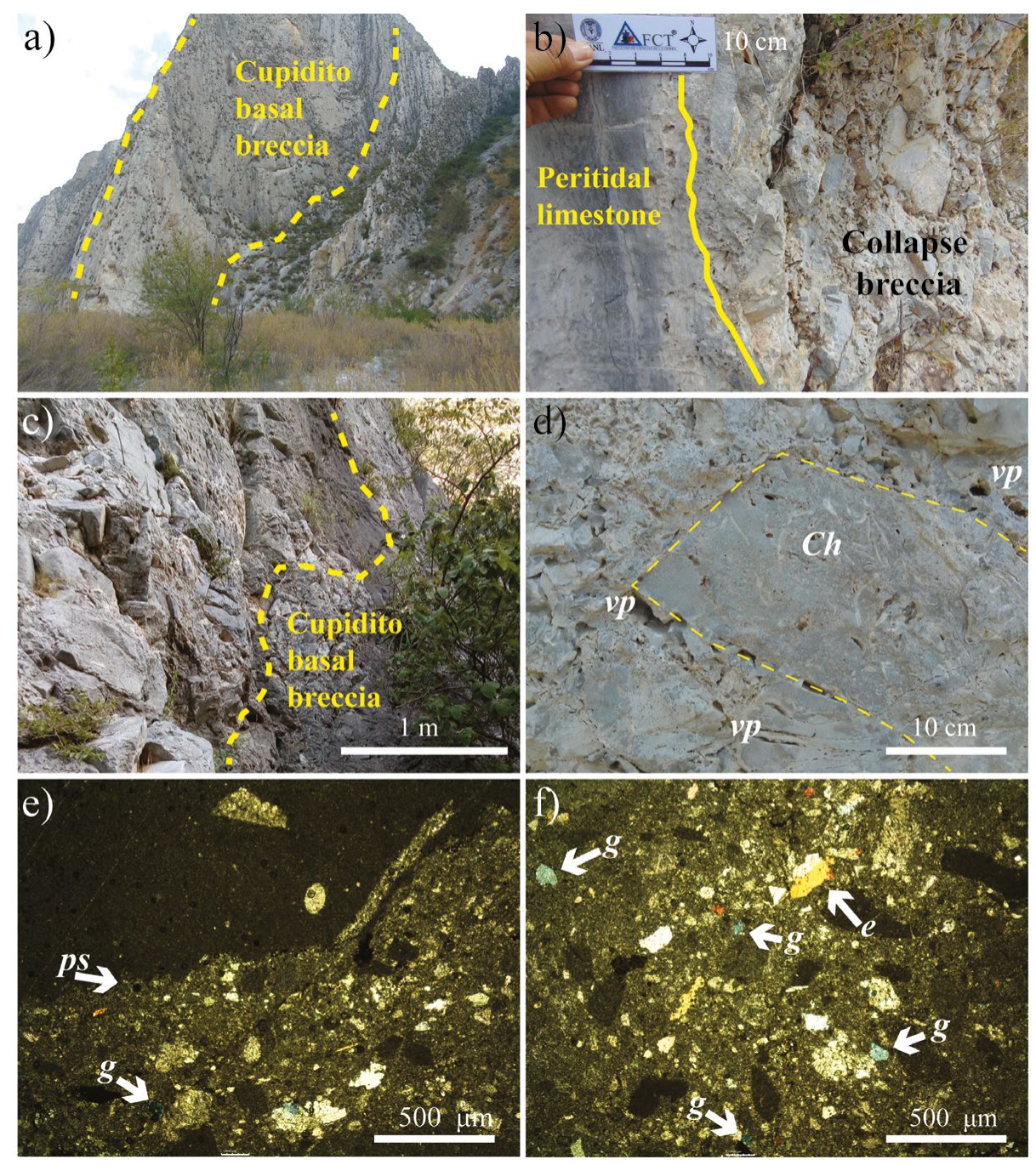

Figure 6. The Cupidito unit. (a) The erosive Sequence Boundary occurs as an irregular dashed line. (b) Basal collapse breccia in LH. (c) Basal breccia in LM. (d) Limestone fragments (yellow dashed line) with abundant Chondrodonta bivalves (Ch), and vugular porosity $(v p)$ in LH. (e and f) Petrographic thin-sections of the basal collapse breccia and irregular grains of hematite, glauconite, clay minerals and some evaporitic crystals in LH. $(p s)$ pressure-solution; $(g)$ glauconite; $(e)$ evaporate crystals.

be confused with the basal part of the La Peña Formation. The variation of the orientation of Chondrodontes shells reflects changes in the energy level of the water, most of the shells are parallel to the stratification; in turn, this indicates a rapid winnowing, low sedimentation rates and reworking of deposits (Ayoub-Hannaa and Fürsich, 2011).

\section{Depositional model}

The Carbonera Formation in the southeastern part of the Coahuila Block underlies the Cupido Formation and was proposed as a siliciclastic sequence from the Lower Cretaceous (Neocomian) with its source in the Coahuila Block (Eguiluz de Antuñano, 1990). The deltaic sandstones from the Sandy Galeana Member (SGM), with its source in the Tamaulipas Island, has been proposed for localities exposed in areas such as Rayones, Galeana and Potrero Prieto (Ocampo-Díaz et al., 2012). Within this depositional context, the age variation in the base of the Cupido Formation may be related to the late siliciclastic sedimentation that could inhibit or retard the fixation of carbonate sequences; this scenery is congruent with the observation of a high lateral variation of the Cupido Formation, which is the most notable feature in Cupido, especially at its lower limit. In Potrero de Menchaca, the system Cupido/Cupidito overlies La Virgen Formation (Eguiluz de Antuñano, 2011; Gutierrez-Alejandro et al., 2017). In La Muralla (LM), Cupidito is recognizable as a regressive deposits overlying La Mula Formation. The lateral variation of underlying formations is a natural characteristic for extended formations with a transgressiveregressive affinity.

The geographic orientation of the Cupido margin exhibits a sharp "dogleg" morphology that trends toward Galeana (Lehmann et al., 1998) and signal a further effect of the siliciclastic alignment of the Cupido Formation. According to Wilson (1999), a telescopic effect compressed the Cupido strata into a southeast-orientation activated by the Laramide orogeny. Moreover, Kleist et al. (1984) documented a counterclockwise orientation at the southeast corner of the Coahuila Block (in Los Chorros, LC), probably also activated by the Laramide orogeny. These results suggest that the inherited paleo-topography from the siliciclastic alignment of the Saltillo Delta and the Sandy Galeana Member, may have controlled the geometry of the Cupido Formation margin in the Monterrey-Galeana-Saltillo area (Figure 10). 
The peculiar occurrence of a basal stratigraphic breccia found only in PCH but not in any other locality, provides further elements to infer a probable talus generated at this point. The fact that a massive body of reef limestones with abundant rudists directly overlies this breccia, suggests an eastward progradation from the very lower part of the Cupido Formation. Reef facies formed by large Toucasia and Chondrodontes quickly prograded after aggradation cycles, as observed in PCH and LH. These reef facies are also present in the basal Cupido Formation in PM (Torres de la Cruz, 2014; Torres de la Cruz et al., 2018). Spongy mud mounds developed along a carbonate ramp (inherited from the Taraises Formation) characterize the base of the Cupido Formation in Bustamante canyon (Murillo-Muñetón and Dorobek, 2003). These mud-mounts evolved to coral-stromatoporoid- rudist bioherms throughout a regressive stage that eventually modified the depositional profile into a reef-rimed platform (Figures 10 and 11). Although, these mud-mounds are not developed (or preserved) in all localities, the presence of morphologically-variable organic buildups is a feature that reflects oligothrophic conditions near the instauration of the MFS of the Taraises Formation, which is likely related to local paleo-reliefs inherited from structures below.

On the other hand, the presence of stratiform microbial mats, commonly indicating restricted conditions of high salinity and low energy (Logan et al., 1974) in cyclic alternation with bioturbation, also suggest several transgressive episodes between regression and subsidence rates that generated embayments. This restricted circulation also promoted intermittent rehydration and evaporative conditions within


Figure 7. Cupidito Diagnostic Facies. (a, c and e) Domal stromatolites with a higher convexity trend. (b) Fenestral microbial laminated fabric. (d) Lamination couplets with a narrow dark laminae (small arrow) followed by a fenestrated thicker-light laminae. (e) Gently-convex lamination with elongate fenestrae and vugular porosity. (f) Cherty nodules in uppermost Cupidito (PCH and LM). (g-h) Chondrodonta in PM and LM localities. (i-j) Cyclical bioturbation horizons (white arrow) alternating with stratiform microbial mats (black arrow). (k-l) Calcite nodules in Cupido and Cupidito. 

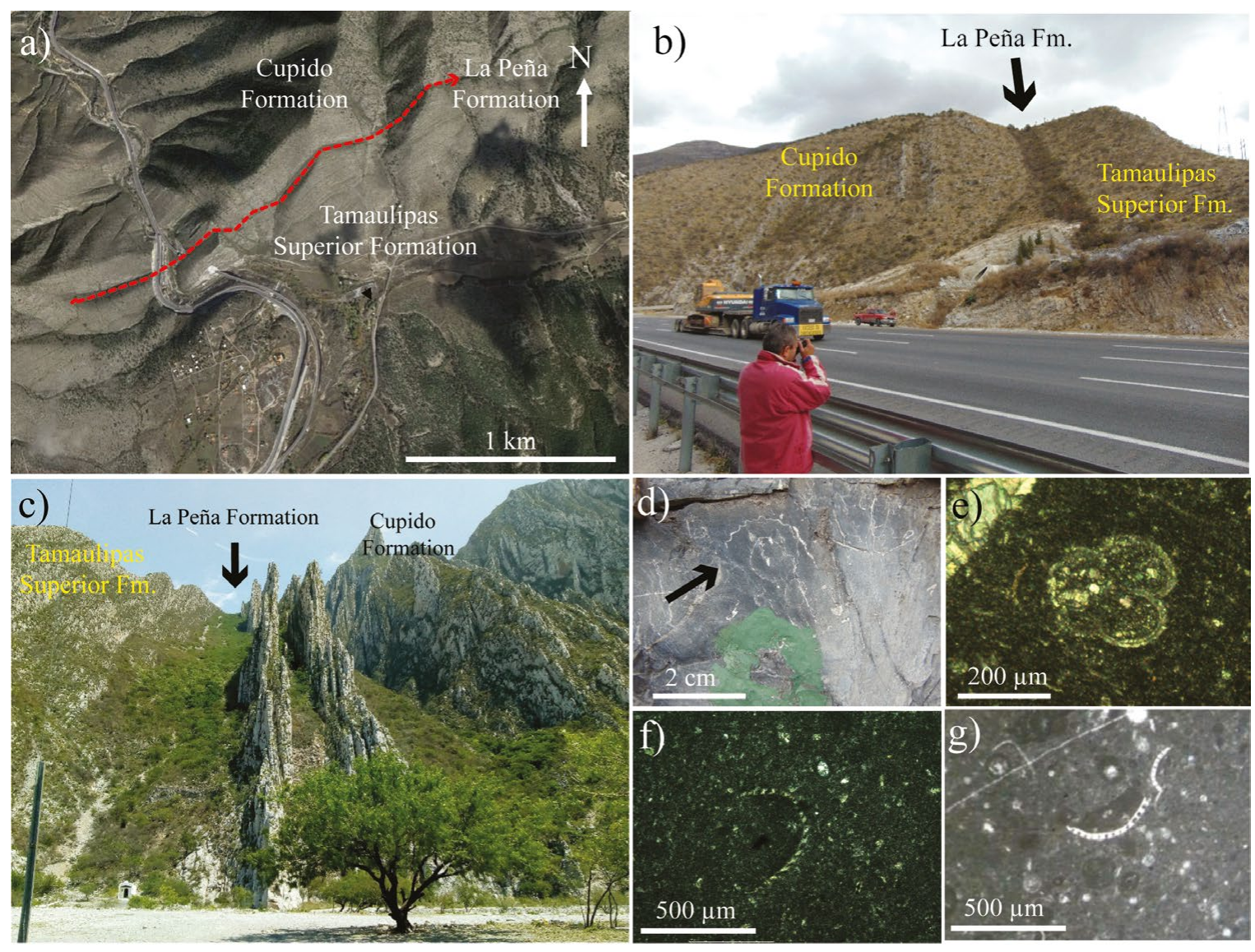

Figure 8. La Peña and Tamaulipas Superior formations. (a) Satellite view of the south flank of LC in red arrow, the La Peña Formation. (b) Panoramic view of the vegetation dividing line among La Peña (black arrow), Cupido and the Tamaulipas Superior formations at LC. (c) A saddle mountain uplift of La Peña Formation in LH. (d) Preserved ammonite, (e) Foraminifera in LC. (f, g) Microcalamoides sp. from the Tamaulipas Superior Formation in LH and PGr.

Table 2. Carbon and oxygen isotopic values and temperatures estimated for Puerto Mexico (PM), La Huasteca (LH) and Potrero de García (PGr).

\begin{tabular}{llrrr}
\hline Sample & & $\begin{array}{c}\boldsymbol{\delta}^{13} \mathbf{C} \\
(\% \text { PDB })\end{array}$ & $\begin{array}{c}\boldsymbol{\delta}^{18} \mathbf{O} \\
(\% \text { PDB })\end{array}$ & $\begin{array}{c}\text { T } \\
\left({ }^{\circ} \mathrm{C}\right)\end{array}$ \\
\hline Puerto Mexico & & & & - \\
PM-Cp-str1 & Stromatolitic travertine & -6.79 & -7.52 & - \\
PM-1C-str & Stromatolitic travertine & -7.92 & -7.23 & 31.5 \\
6-CP-PM-02 & Coral & 0.43 & -5.27 & 32.2 \\
Cp-PM-coral & Coral & 0.75 & -5.43 & \\
La Huasteca & & & & 25.3 \\
Cpdo-Ht & Grey limestone & 2.91 & -3.98 & 29.6 \\
Ht-Cp-calc. & Dark limestone & 3.41 & -4.89 & 23.8 \\
Ht-0-30b-S12 & Host rock rudist & 3.60 & -3.64 & - \\
LH-Travertine & Travertine (LH) & -5.59 & -8.07 & 35 \\
Brechased & Solution breccia & -8.31 & -5.99 & \\
Potrero de García & & & & 48.3 \\
Gr-Cp-str & Stromatolite & 0.93 & -8.56 & 39.2 \\
CpG04 & Microbial mat & 1.71 & -6.83 & 30.2 \\
Gr-CUPIDO FORMATION-MAT & Microbial mat & 2.96 & -5 & 32.4 \\
CpG16 & Mudstone with benthic foraminifera & 2.69 & -5.46 \\
Gr-CUPIDO FORMATION-calcx & Limestone & 2.86 & -4.74 & 28.9 \\
CpG10 & Wackestone with benthic foraminifera & 3.15 & -5.47 & 32.4 \\
\hline
\end{tabular}




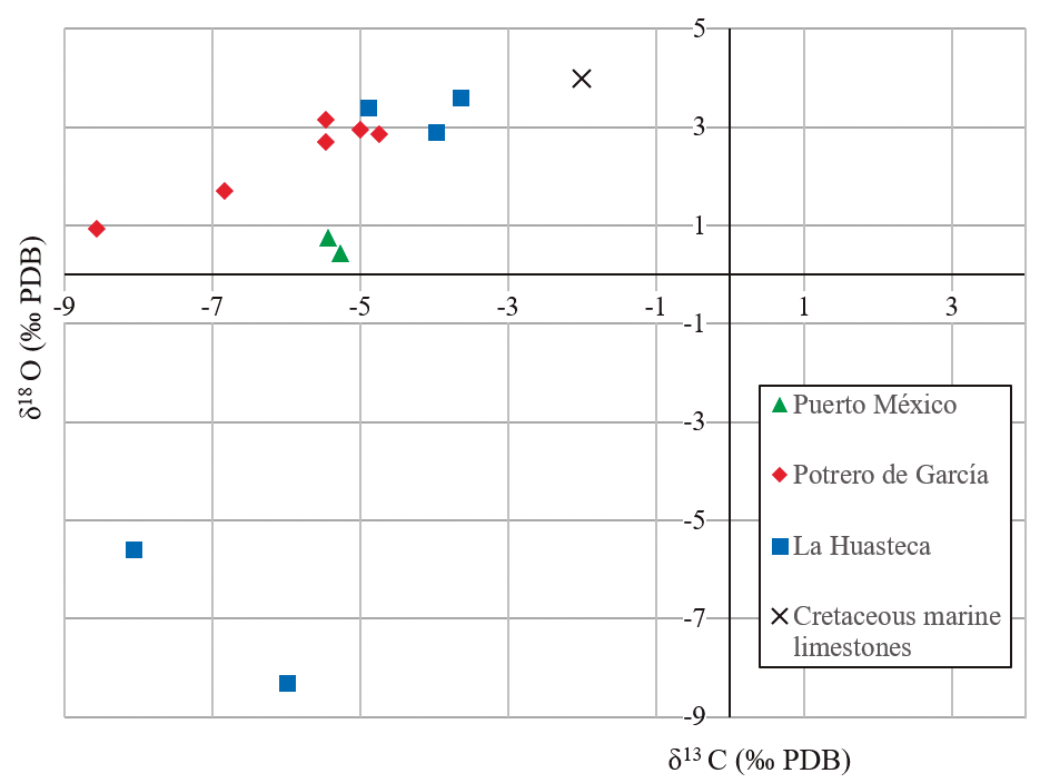

Figure 9. Cross-plot of $\delta^{13} \mathrm{C}$ PDB $v s \delta^{18} \mathrm{O}$ PDB values from this work compared with other published isotopic carbonate values (Moldovany and Lohmann, 1984).

the platform interior that reflect on the alternating bioturbation/mats facies. These low amplitude and high frequency peritidal limestone are also result of the Milankovitch cycle variations and, to a smaller scale, of the local climatic changes by authigenic processes (Lehmann $e t$ al., 1998). Furthermore, the alternation between bioturbated beds and microbial mats indicate uniform shallow paleoenvironmental conditions with periodic eustatic changes related to a flat-topped platform. This platform may have extended as far as LM at the north, and as far as PM to the south (Figure 1). Both localities are linearly separated by $140 \mathrm{~km}$. If tectonic shortening is omitted, which is estimated at least in $37 \%$ at the Santa Rosa canyon, Nuevo León (Chávez-Cabello et al., 2011), and in 33\% between Monterrey and Aramberri (Eguiluz de Antuñano et al., 2000), then this area used to be larger than the actual size.

These results confirm the general observation that peritidal sequences are mostly present in the platform interior (Figures 10 and 11). The Cupidito Unit (Wilson and Pialli, 1977) defined as retrogradational lagoon limestones that marks the beginning of the drowning episode of Coahuila Block, known as the Gargas event (Barragán Manzo and Díaz-Otero, 2004). The drowning of the Cupido platform in northeastern Mexico has been acknowledged locally and regionally as the "Gargas" and "Selli" events, respectively (Föllmi et al., 1994; Barragán Manzo and Díaz-Otero, 2004; Núñez-Useche et al., 2014). Although the evidences for a drowning platform event are typically provided by seismographical data (Ferreri et al., 2004), there are some field clues that document this event. The most diagnostic characteristics of Cupidito is the development of a collapse breccia generated by a discordant erosive surface (yellow belts in Figure 11) that coincides with a global decrease of the relative sea level approximately $124 \mathrm{Ma}$ ago (Ogg et al., 2004).

As evidenced in $\mathrm{LH}$ and $\mathrm{PCH}$, the sequence boundary is characterized by several collapse breccias (Conklin and Moore, 1977). This Sequence Boundary was established in northeastern Mexico either at $112 \mathrm{Ma}$ (Goldhammer, 1999) or at $124 \mathrm{Ma}$ (Eguiluz de Antuñano, 2011). This Sequence Boundary (SB) is classified as Type I according to Van Wagoner et al. (1990). The SB is reported in Texas as the base of the upper part of the Sligo Formation (Eguiluz de Antuñano, 2011; Goldhammer, 1999; Wilson and Pialli, 1977). Nice examples of this breccia are present in $\mathrm{LH}$ and PCH, but not in PM or LC. The devel- opment of breccias, therefore, may have been selective and especially promoted by topographic highs. In areas where La Virgen was not deposited, Cupidito is only recognizable because of its erosive surface (Eguiluz de Antuñano, 2011).

\section{Paleotemperatures}

Moldovanyi and Lohmann (1984) established the Early Cretaceous Marine Limestones Base Line (ECMLBL) with the heaviest isotopic values deriving from the Cupido and Sligo formations limestones (Figure 9), which range between $1.8 \%$ and $4.0 \%$ for $\delta^{13} \mathrm{C}$ and between $-2 \%$ and $-5 \%$ for $\delta^{18} \mathrm{O}$. Other estimates for $\delta^{18} \mathrm{O}$ yielded values as low as $-2.5 \%$ for oxygen and between 2.5 and 4.0 for $\delta^{13} \mathrm{C}$ in AptianAlbian shallow marine carbonates (Scholle and Arthur, 1980). Since organisms generate their skeletons in isotopic equilibrium with sea water (Erez and Luz, 1983), the isotopic values derived from corals, rudists and stromatoporoids from the Cupido Formation may reflect their local paleo-environmental conditions. The values plotted in the second quadrant of Figure 9 corresponds to normal marine limestone according to Hudson (1977), Nelson and Smith (1996), as well as to data reported in the literature (Table 2).

The higher temperature values from lithified microbial mats $\left(39.2^{\circ} \mathrm{C}\right)$ and small stromatolites $\left(48.3^{\circ} \mathrm{C}\right)$ could be explained by the environmental settings where microbialites developed. In contrast, lower temperatures derive from lagoon samples $\left(13.8\right.$ and $\left.25.3^{\circ} \mathrm{C}\right)$. The resulting temperatures for $\mathrm{PM}$ corals $\left(31.5^{\circ} \mathrm{C}\right.$ and $\left.32.2^{\circ} \mathrm{C}\right)$ are similar to values calculated by Leal-Resendez (2009) and Caballero-Ramirez (2010) for the PCH locality. The average temperatures for Cupidito in PCH (oscillating between $31-33^{\circ} \mathrm{C}$ ), are comparable with early Aptian Equatorial Pacific paleotemperatures derived from the Deep See Drilling Project $\left(30-32{ }^{\circ} \mathrm{C}\right.$ ) at a paleolatitude of $\sim 20^{\circ} \mathrm{S}$ (Schouten et al., 2003). According to van Hinsbergen et al. (2015), the Cupido area was located close to paleolatitude $30^{\circ} \mathrm{N}$ during the Barremian. The PM corals paleotemperature fits well within these values too; furthermore, it is probable that these paleotemperatures are closest to the real Cupido Formation values, since corals need crystalline waters for photosynthesis, which in turn generates low heavy carbon isotope values. 
Table 3. Comparative $\delta^{13} \mathrm{C}$ and $\delta^{18} \mathrm{O}$ for the Cupido Formation and other similar localities.

\begin{tabular}{|c|c|c|c|}
\hline Author & Sample & $\delta^{13} \mathrm{C}(\%$ PDB $)$ & $\delta^{18} \mathrm{O}(\% \mathrm{PDB})$ \\
\hline \multicolumn{4}{|l|}{ Marine limestones indicators } \\
\hline Moldovanyi and Lohmann (1984) & Early Cretaceous marine carbonate baseline & -2 & 4 \\
\hline \multirow[t]{2}{*}{ This study } & Coral (PM) & 0.75 & -5.43 \\
\hline & & 0.43 & -5.7 \\
\hline \multirow[t]{2}{*}{ Guzzy-Arredondo et al. (2007) } & Rudist (Bustamante Canyon) & 0.5 & -6.2 \\
\hline & & 2.5 & -4.4 \\
\hline \multirow[t]{4}{*}{ Murillo-Muñetón and Dorobek (2003) } & Dark dense micrite & 1.85 & -4.5 \\
\hline & & 2.19 & -4.79 \\
\hline & & 2.2 & -4.85 \\
\hline & Micrite of calcisponge & 1.72 & -6.38 \\
\hline \multirow[t]{2}{*}{ Monroy-Santiago (2012) } & Rudist (La Escalera) & 3.95 & -3.25 \\
\hline & & 3.89 & -3.49 \\
\hline \multicolumn{4}{|l|}{ Average freshwater limestones indicators } \\
\hline \multirow[t]{4}{*}{ This study } & Collapse breccia (LH) & -8.31 & -5.99 \\
\hline & Travertine (LH) & -5.59 & -8.07 \\
\hline & Stromatolitic structure (PM) & -6.79 & -7.51 \\
\hline & & -7.92 & -7.22 \\
\hline \multirow[t]{11}{*}{ Monroy-Santiago (2012) } & Collapse breccia & 1.41 & -3.85 \\
\hline & & -0.95 & -5.44 \\
\hline & & -1.85 & -5.44 \\
\hline & & -0.3 & -15.45 \\
\hline & Anhydrite nodules replaced by calcite & 2.2 & -3.12 \\
\hline & & -9.19 & -4.965 \\
\hline & & -7.03 & -6.46 \\
\hline & Travertine & -6.37 & -9.43 \\
\hline & & -7.18 & -8.44 \\
\hline & & -4.94 & -8.23 \\
\hline & & -10.75 & -7.4 \\
\hline \multicolumn{4}{|l|}{ Microbiologically induced } \\
\hline \multirow[t]{3}{*}{ This study } & Stromatolite (PGr) & 0.93 & -8.56 \\
\hline & Microbial Mats (PGr) & 2.96 & -5 \\
\hline & & 1.71 & -6.83 \\
\hline Murillo-Muñetón and Dorobek (2003) & $\begin{array}{l}\text { Microbial crust } \\
\text { (most frequent and average) }\end{array}$ & 1.83 & -6.67 \\
\hline Leal-Resendez (2009) and Caballero-Ramirez (2010) & Most frequent values from Cupidito $\mathrm{PCH}$ & 4 & -5 \\
\hline
\end{tabular}

Although the possibility of diagenetic overprinting of primary oxygen and carbon isotopic values may be high by burial and compactation, the comparison of isotopic signals among contemporaneous sections of this complex platform system helps to obtain a general view of diagenetic processes and local differences among localities. The inferred paleotemperatures for most Cretaceous carbonates are always subject to corrections by diagenetic overprint (Fischer et al., 1989; Frank et al., 1999; Frank and Bernet, 2000; Parente et al., 2007), and yet, the extend of diagenetic effects has been scarcely addressed. This data may help to constrain sampling points for isotope analysis, too.

\section{CONCLUSIONS}

Because of the large thickness of the Cupido Formation, extensive sedimentary facies are well-exposed in representative localities of northeastern Mexico. Especially relevant are those peritidal carbonate facies that may serve as reservoir rocks and proved analogues overlapped by La Peña Formation as a regional seal.

Based on these results and especially on the proposed model that summarizes the Cupido Formation, it could be speculated that the age variation in the Cupido Formation base could be related to siliciclastic sequences from the Saltillo Delta and the Sandy Galeana Member. Particularly, the basal part of Cupido at $\mathrm{PCH}$ is identified by a talus breccia with a progradational affinity at the earliest depositional stage. Under this scenario, it can be inferred that $\mathrm{PCH}$ represents a platform edge remains at the beginning of the Cupido deposition. Cupidito may be regarded as a drowning discontinuity between the Cupido Formation and La Peña Formation. Since Cupidito contains scientific and potential economic relevance, this sedimentary unit should be recognized as a formally-acknowledged member of the Cupido Formation, according to the criteria established by the Código Estratigráfico Norteamericano (Barragán et al., 2010). 


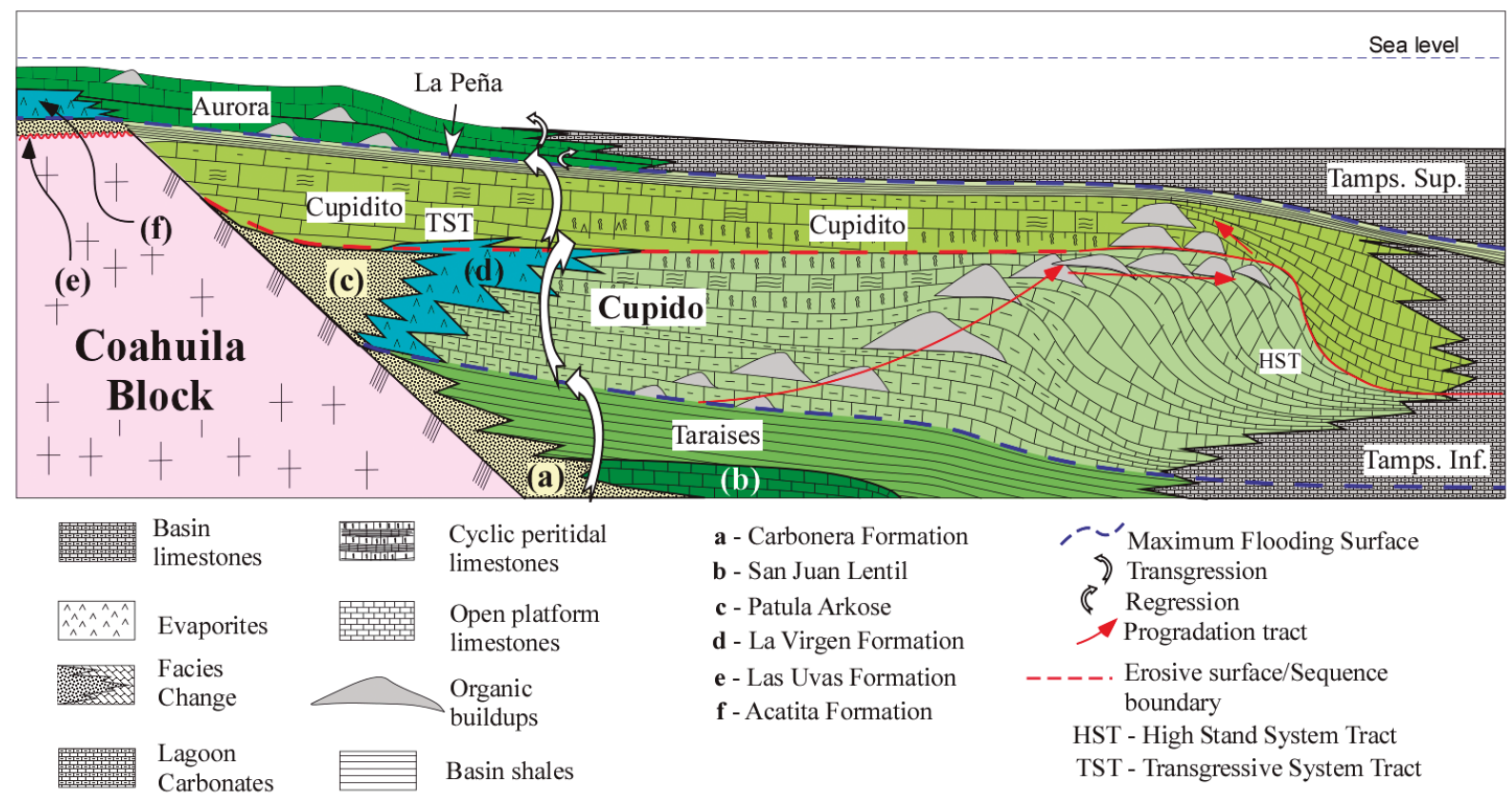

Figure 10. The evolution of the Cupido Formation. A schematic stratigraphic NW-SE section from Upper Jurassic to upper Aptian.

The analyzed peritidal sequences suggest the development of a top-flat carbonate platform in equilibrium with regression and subsidence events. Both processes maintained the aggradation rate of the Cupido peritidal platform, widely extended in northeastern Mexico at that time. Microbial carbonate horizons indicate embayment episodes that produced restricted circulation and probable hypersaline conditions, excluding most of the benthic biota. A low organic productivity environment may be the result of changes in regression and subsidence rates. The occurrence of numerous bioturbation horizons concentrated mainly toward the platform edge remains an open question.

\section{ACKNOWLEDGMENTS}

Field data used in this study is part of the $\mathrm{PhD}$ research project of F. J. Torres de la Cruz, which has been supported by CONACyT (PhD scholarship 2016-2019). We thanks the help of Facultad de Ciencias de la Tierra, UANL for providing vehicles, gas, chauffeur and necessary infrastructure. The partial assistance of the PROFOCIE SEP through the FCT Graduate Program is much appreciated. The authors would like to thank to F. Núñez-Useche for fruitful discussion and recommendations. We also thanks Prof. Blanca Buitrón and an anonymous reviewer for all suggestions and comments. We especially thanks the professional guidance and editing work of Dr. Peter Schaaf.

\section{REFERENCES}

Amsbury, D., 2000, Evolution of Cupido and Coahuila carbonate platforms, Early Cretaceous, northeastern Mexico: Discussion and reply: Geological Society of America Bulletin, 122, 799-800.

Anderson, T.F., Arthur, M.A., 1983, Stable isotopes of oxygen and carbon and their application to sedimentological and palaeoenvironmental problems, in Arthur, M.A., Anderson, T.F., Kaplan, I.R., Veizer, J., Land, L.S., (eds.), Stable Isotopes in Sedimentary Geochemistry: Dallas, Texas, Society of Economic Paleontologists and Mineralogists, 1-151.
Ángeles-Villeda, M.E., Hinojosa-Espinosa, J.J., López-Oliva, J.G., ValdésGonzález, A., Livas-Vera, M., 2005, Estratigrafía y microfacies de la parte sur del Cañón La Boca, Santiago, Nuevo León, México: Revista Mexicana de Ciencias Geológicas, 22(2), 272-281.

Ayoub-Hannaa, W., Fürsich, F.T., 2011, Functional morphology and taphonomy of Cenomanian (Cretaceous) oysters from the eastern Sinai Peninsula, Egypt: Palaeobiodiversity and Palaeoenvironments, 91 (3), 197-214.

Barragán-Manzo, R., Díaz-Otero, C., 2004, Análisis de microfacies y datos micropaleontológicos de la transición Barremiano-Aptiano en la Sierra del Rosario, Durango, México: Revista Mexicana de Ciencias Geológicas, 21(2), 247-259.

Barragán, R., Campos-Madrigal, E., Ferrusquía-Villafranca, I., López-Palomino, I., Tolson, G., 2010, Código estratigráfico norteamericano, Traducción, Boletín 117, UNAM, 64 pp.

Caballero-Ramirez, V.H., 2010, Análisis paleoambiental del noreste de México mediante el uso de microfacies e isótopos estables de $\delta^{18} \mathrm{O}$ y $\delta^{13} \mathrm{C}$ en la parte superior de la Unidad Cupidito en Potrero Chico, Hidalgo, Nuevo León: Linares, Nuevo León, México, Universidad Autónoma de Nuevo León, Facultad de Ciencias de la Tierra, bachelor thesis, $144 \mathrm{pp}$.

Cantú-Chapa, A., 1989, La Peña Formation (Aptian): a condensed limestoneshale sequence from the subsurface of NE Mexico: Journal of Petroleum Geology, 12(1), 69-84.

Chávez-Cabello, G., Aranda-Gómez, J. J., Molina-Garza, R. S., Arvizu-gutiérrez, I. R. 2005, La falla San Marcos: una estructura jurásica de basamento multirreactivada del noreste de México. Boletín de la Sociedad Geológica Mexicana, 57(1): 27-52.

Chávez-Cabello, G., Torres Ramos, J.A., Porras Vázquez, N.D., Cossio Torres, T., Aranda Gómez, J.J., 2011, Evolución estructural del frente tectónico de la Sierra Madre Oriental en el Cañón Santa Rosa, Linares, Nuevo León: Boletín de la Sociedad Geológica Mexicana, 63(2), 253-270.

Conklin, J., Moore, C., 1977, Paleoenvironmental analysis of the Lower Cretaceous Cupido Formation, northeast Mexico, in Bebout, D.G. Loucks, R.G. (eds.), Cretaceous Carbonates of Texas and Mexico: Austin, Texas, The University of Texas, Bureau of Economic Geology, Report of Investigations No. 89, 302-323.

D'Argenio, B., Ferreri V., Amodio S., 2008, Sequence stratigraphy of Cretaceous carbonate platforms: a cyclostratigraphic approach, in Amorosi, A., Haq, B.U., Sabato L. (eds.), Advances in Application of Sequence Stratigraphy in Italy: GeoActa Special Publication, 1, 157-171.

Dunham, R.J., 1962, Classification of Carbonate Rocks according to Depositional 


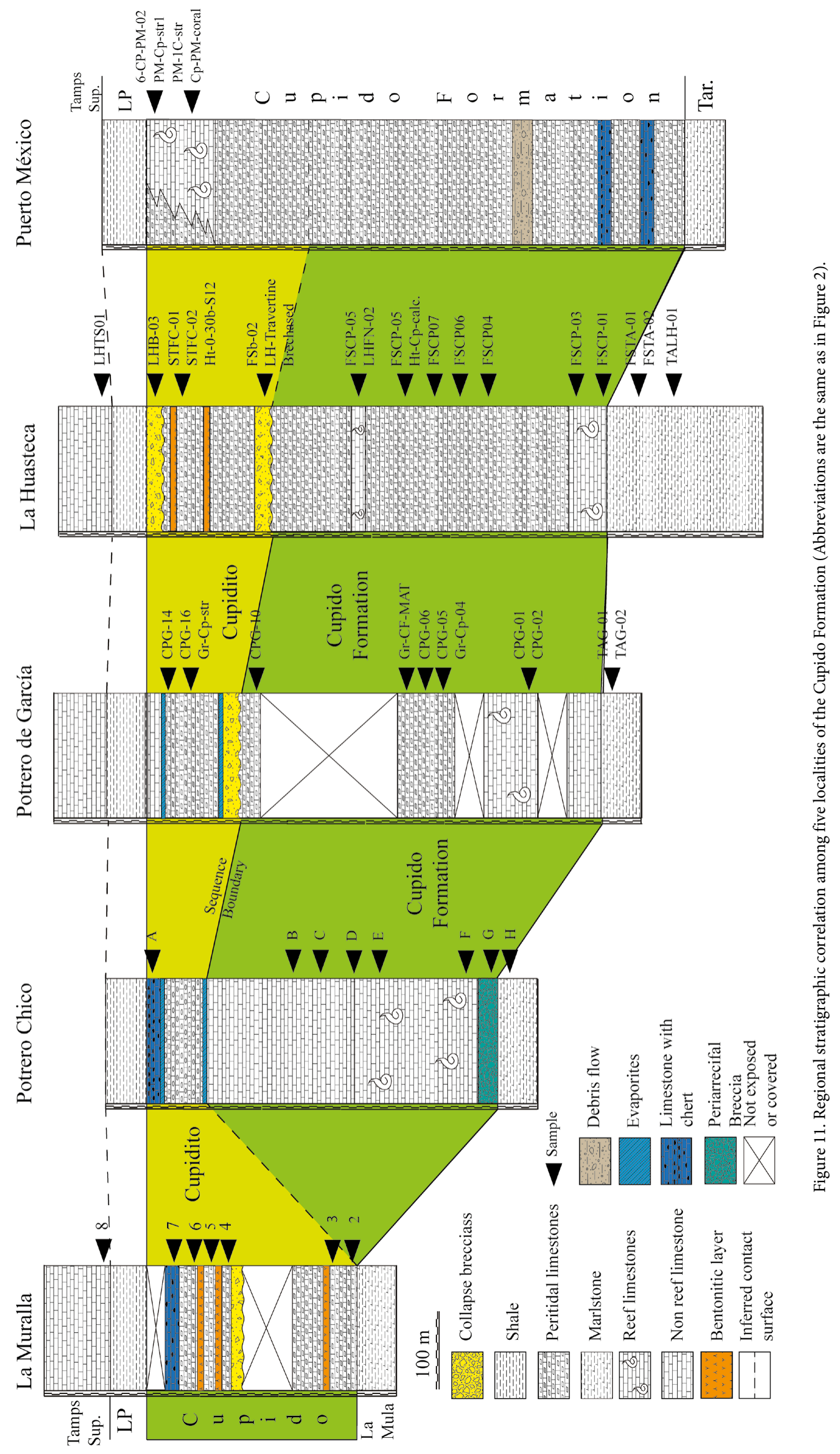


Texture, in Ham W.E. (ed.), Classification of Carbonate Rocks: Tulsa, Oklahoma, USA, American Association of Petroleum Geologists, Memoir $1,108-121$

Echanove, O., 1986, Geología Petrolera de la Cuenca de Burgos (Parte I) Consideraciones geologico-petroleras: Boletín de la Asociación Mexicana de Geólogos Petroleros, 38(1), 3-39.

Eguiluz de Antuñano, S., 1990, La Formación Carbonera y sus implicaciones tectónicas, estados de Coahuila y Nuevo León: Boletín de la Sociedad Geológica Mexicana, 50(1), 3-39.

Eguiluz de Antuñano, S., 2001, Geologic Evolution and gas resources of the Sabinas Basin in northeastern Mexico, in Bartolini, C., Buffler, R.T., Cantú-Chápa, A., (eds.), The Western Gulf of Mexico Basin, Tectonics, Sedimentary Basins, and Petroleum Systems: Tulsa, Oklahoma, U.S.A., American Association of Petroleum Geologists Memoir No. 75, 241-270.

Eguiluz de Antuñano, S., 2011, Secuencias estratigráficas del BerriasianoAptiano en la Cuenca de Sabinas: su significado en el entendimiento de la evolución geológica del noreste mexicano: Boletín de la Sociedad Geológica Mexicana, 63(2), 285-311.

Eguiluz de Antuñano, S., Aranda García, M., Marrett, R., 2000, Tectónica de la Sierra Madre Oriental, México: Boletín de la Sociedad Geológica Mexicana, 53(1), 1-26.

Erez, J., Luz, B., 1983, Experimental paleotemperature equation for planktonic foraminifera: Geochimica et Cosmochimica Acta, 47(6), 1025-1031.

Ferreri, V., Amodio, S., Sandulli, R., Dárgenio, B., 2004, Orbital Chronostratigraphy of the Valanginian-Hauterivian boundary: A cyclostratigraphic approach, in D’Argenio, B., Fischer, A.G., Premoli Silva, I., Weissert, H., Ferreri, V. (eds.), Cyclostratigraphy: Approaches and Case Histories: Tulsa, OK., Society for Sedimentary Geology, SEPM Special Publication, 81, 153-166, https://doi.org/10.2110/pec.04.81.0153

Fischer, A.G., De Boer, P.L., Premoli Silva, I., 1989, Cyclostratigraphy, in: Ginsburg, R.N., Beaudoin, B. (eds.), Cretaceous Resources, rithms, and events: Background and Plans for Research: Dordrecht, Holland, NATO ASI Series, Kluwer, 139-172.

Fischer, M.P., Jackson, P.B., 1999, Stratigraphic controls on deformation patterns in fault-related folds: A detachment fold example from the Sierra Madre Oriental, northeast Mexico: Journal of Structural Geology, 21(6), 613-633.

Folk, R.L. 1959. Practical petrographic classification of limestones. Bulletin of the American Association of Petroleum Geologists, 43(1): 1-38.

Folk, R.L. 1962. Spectral subdivision of limestone types, in Ham, W.E. (ed.), Classification of carbonate rocks: Tulsa, OK., American Association of Petroleum Geologists, 1, 62-84.

Föllmi, K.B., Weissert, H., Bisping, M., Funk, H., 1994, Phosphogenesis, carbonisotope stratigraphy, and carbonate-platform evolution along the Lower Cretaceous northern Tethyan margin: Geological Society of America Bulletin, 106 (6), 729-746.

Fortunato, K.S., Ward, W.C., 1982, Upper Jurassic-Lower Cretaceous Fan-Delta complex: La Casita Formation on the Saltillo area, Coahuila, Mexico: Transection Gulf Coast Association of Geological Societies, 32, 473-482.

Frank, T.D., Bernet, K., 2000, Isotopic signature of burial diagenesis and primary lithological contrast in periplatform carbonates (Miocene, Great Bahama Bank): Sedimentology, 47(6), 1119-1134.

Frank, T.D., Arthur, M.A., Dean, W.E., 1999, Diagenesis of Lower Cretaceous pelagic carbontaes, North Atlantic: Paleoceanographic signals obscured: Journal of Foraminiferal Research, 29(4), 340-351.

Goldhammer, R.K., 1999, Mesozoic sequence stratigraphy and paleogeographic evolution of northeast Mexico, in Bartolini, C., Wilson, J.L., Lawton, T.F (eds.), Mesozoic Sedimentary and Tectonic History of North-Central Mexico: Boulder, Colorado, Geological Society of America Special Paper 340, 1-58.

Goldhammer, R.K., Johnson, C.A, 2001, Middle Jurassic-Upper Cretaceous Paleogeographic Evolution and Sequence-stratigraphic Framework of the Northwest Gulf of Mexico Rim, in Bartolini, C., Buffler, R.T., Cantu-Chapa, A. (eds.), The Western Gulf of Mexico Basin: Tectonics, Sedimentary Basins, and Petroleum Systems: Tulsa, Oklahoma, American Association of Petroleum Geologists Memoir 75, 45-81.

Goldhammer, R.K., Lehmann, C., Todd, R.G., Wilson, J.L., Ward, W.C., Johnson, C.R., 1991, Sequence stratigraphy and cyclostratigraphy of the Mesozoic of the Sierra Madre Oriental, northeast Mexico, a field guide book: Austin, Texas, Gulf Coast Section, Society of Economic Paleontologists and
Mineralogists, Foundation Special Publications in Geology No. 2, 86 pp.

Gómez-Mancha, Y.E., 2016, Estudio de los principals mecanismos de Fosilización en rocas de la Formación Cupido, Barremiano-Aptiano del Noreste de México: Nuevo León, México, Facultad de Ciencias de la Tierra, Universidad Autónoma de Nuevo León, bachelor thesis, 125 pp.

González-Fernández, B., Menéndez-Casares, E., Vicedo, V., Aramburu, C., Caus, E., 2014, New insights about the Upper Jurassic - Lower Cretaceous sedimentary successions from Asturias (NW Iberian Peninsula): Journal of Iberian Geology, 40(3), 409-430

Guerrero-Moreno, J.G., 2018, Pre-Andean tectonic events from albian to Eocene in the middle Magdalena valley and situation of the Western flank of the proto-eastern cordillera (Colombia): Universidad de Colombia and Université Grenoble Alpes, $\mathrm{PhD}$ thesis, $480 \mathrm{pp}$.

Gutierrez-Alejandro, A.G., Chacón-Baca, E., Rosales-Domínguez, C., RamírezPeña, C.F., Girón, P., Grajales-Nishimura, J.M., 2017, A clastic-evaporitic deposit from the Cretaceous of northeastern Mexico: La Mula-La Virgen transition: Journal of South American Earth Sciences, 80, 411-421.

Guzmán-García, J., 1991, Evaluación geológica petrolera del Golfo de Sabinas: Petróleos Mexicanos, Informe Técnico NE-M 2362, 72 p. (unpublished).

Guzzy-Arredondo, G.S., Murillo-Muñetón, G., Morán-Zenteno, D.J., GrajalesNishimura, J.M., Martínez-Ibarra, R., Schaaf, P., 2007, High-temperature dolomite in the Lower Cretaceous Cupido Formation, Bustamante Canyon, northeast Mexico: petrologic, geochemical and microthermometric constraints: Revista Mexicana de Ciencias Geológicas, 24(2), 131-149.

Hernández-Trejo, J.M., 2003, Cicloestratigrafía en un sistema carbonatadoevaporitico del Cretácico Inferior, Formación La Virgen, noreste de México: Mexico City, Instituto Politécnico Nacional, Escuela Superior de Ingeniería y Arquitectura, Unidad Ticomán, M.Sc. thesis, 86 pp.

Hudson, J.D., 1977, Stable isotopes and limestone lithification: Journal of the Geological Society of London, 133(6), 637-660.

Humphrey, W.E., 1949, Geology of the Sierra de los Muertos area, Mexico (with descriptions of Aptian Cephalopods from the La Peña Formation): Geological Society of America Bulletin, 60(1), 89-176.

Humphrey, W.E., Díaz, T., 2003, Jurassic and Lower Cretaceous Stratigraphy and Tectonics of Northeast Mexico: Austin, Texas, Bureau of Economic Geology Report of Investigation No. 267, 151 pp.

Imlay, R.W., 1937, Geology of the middle part of the Sierra de Parras, Coahuila, Mexico: Geological Society of America Bulletin, 48(5), 587-630.

Kleist, R., Hall, S.A., Evans, I., 1984, A paleomagnetic study of the Lower Cretaceous Cupido Limestone, northeast Mexico: Evidence for local rotation within the Sierra Madre Oriental: Geological Society of America Bulletin, 95, 55-60.

Joachimski, M.M., 1994, Subaerial exposure and deposition of shallowing upward sequences: evidence from stable isotopes of Purbeckian peritidal carbonates (basal Cretaceous), Swiss and French Jura Mountains: Sedimentology, 41, 805-824.

Jones, N.W., McKee, J.W., Marquez D., B., Tovar, J., Long, L.E., Laudon, T.S., 1984, The Mesozoic La Mula Island, Coahuila, Mexico: Geological Society of America Bulletin, 95(10), 1226-1241.

Kroeger, K.F., Stinnesbeck, W., 2003, The Minas Viejas Formation (Oxfordian) in the area of Galeana, northeastern Mexico: Significance of syndepositional volcanism and related barite genesis in the Sierra Madre Oriental, in Bartolini, C., Buffler, R.T., Blickwede, J. (eds.), The Circum-Gulf of Mexico and the Caribbean: Hydrocarbon habitats, basin formation, and plate tectonics: Tulsa, Oklahoma, American Association of Petroleum Geologists Memoir 79, 515-528.

Leal-Resendez, I., 2009, Análisis microfacial y geoquímico en calizas de la porción superior de la Formación Cupido en el Potrero Chico, Hidalgo, Nuevo León, México: Linares, Nuevo León, Universidad Autónoma de Nuevo León, bachelor thesis, 151 pp.

Lehmann, C., Osleger, D.A., Montañez, I.P., 1998, Controls on cyclostratigraphy of Lower Cretaceous carbonates and evaporites, Cupido and Coahuila platforms, northeastern Mexico: Journal of Sedimentary Research, 68 (6), 1109-1130.

Lehmann, C., Osleger, D.A., Montañez, I.P., Sliter, W., Arnaud-Vanneau, A., Banner, J., 1999, Evolution of Cupido and Coahuila carbonate platforms, Early Cretaceous, northeastern Mexico: Geological Society of America Bulletin, 111 (7), 1010-1029.

Lehmann, C., Osleger, D.A., Montañez, I., 2000, Sequence Stratigraphy of Lower 
Cretaceous (Barremian-Albian) Carbonate Platforms of Northeastern Mexico: Regional and Global Correlations: Journal of Sedimentary Research, 70(2), 373-391.

Logan, B.W., Hoffman, P., Gebelein, C.D., 1974, Algal Mats, Cryptalgal Fabrics, and Structures, Hamelin Pool, Western Australia, in Logan, B.W., Read, J.F., Hagan, G.M., Hoffman, P., Brown, R.G., Woods, P.J., Gebelein, C.D., (eds.), Evolution and Diagenesis of Quaternary Carbonate Sequences, Shark Bay, Western Australia: Tulsa, Oklahoma, American Association of Petroleum Geologists Memoir 22, 149-194.

McFarlan E.Jr., Menes L.S., 1991, Lower Cretaceous, in: Salvador A. (ed.), The Gulf of Mexico basin, The geology of North America: USA, Geological Society of America, J, 181-204.

Michalzik, D., 1988, Trias bis tiefste Unter-Kreide der nordöslichen Sierra Madre Oriental, Mexico. Fazielle Entwicklung eines passiven Kontinentalrandes: Darmstadt, Deutschland, Technischen Hochschule Darmstadt, PhD thesis, $247 \mathrm{pp}$.

Moldovanyi, E.P., Lohmann, K.C., 1984, Isotopic and petrographic record of phreatic diagenesis: Lower Cretaceous Sligo and Cupido Formations: Journal of Sedimentary Petrology, 54 (3), 972-985.

Monroy-Santiago, F., 2012, Interrelationships Between Carbonate Diagenesis and Fracture Development : Example From Monterrey Salient, Mexico and Implications for Hydrocarbon Reservoir Characterization: Austin, Texas, The University of Texas, $\mathrm{PhD}$ thesis, $345 \mathrm{pp}$.

Murillo-Muñetón, G., Dorobek, S.L., 2003, Controls on the evolution of carbonate mud mounds in the Lower Cretaceous Cupido Formation, Northeastern Mexico: Journal of Sedimentary Research, 73 (6), 869-886.

Nelson, C.S., Smith, A.M., 1996, Stable oxygen and carbon isotope compositional fields for skeletal and diagenetic components in New Zealand Cenozoic nontropical carbonate sediments and limestones: A synthesis and review: New Zealand Journal of Geology and Geophysics, 39(1), 93-107.

Núñez-Useche, F., Barragán, R., Moreno-Bedmar, J.A., Canet, C., 2014, Mexican archives for the major Cretaceous Oceanic Anoxic Events: Boletín de la Sociedad Geológica Mexicana, 66(3), 491-505.

Ocampo-Díaz, Y.Z.E., 2011, Implicaciones tectono-sedimentarias de las intercalaciones clásticas en el límite Jurásico-Cretácico del Noreste de México (Fosa de Monterrey y Cuenca de Sabinas): Linares, Nuevo León, Universidad Autónoma de Nuevo León, PhD thesis, 275 pp.

Ocampo-Díaz, Y.Z.E., Jenchen, U., Guerrero-Suastegui, M., 2008, Facies y sistemas de depósito del miembro arenoso Galeana (Formación Taraises, Cretácico inferior, NE de México): Revista Mexicana de Ciencias Geológicas 25(3), 438-464.

Ocampo-Díaz, Y.Z.E., Guerrero-Suástegui, M., Jenchen, U., 2012, Petrografía y procedencia del miembro arenoso Galeana (Formación Taraises, Valanginiano - Hauteriviano temprano), Sierra Madre Oriental, NE México: Boletín de la Sociedad Geológica Mexicana, 64(3), 335-352.

Ogg, J.G., Agterberg, F.P., Gradstein, F.M., 2004, The Cretaceous Period, in Gradstein, F.M., Ogg, J.G., Smith, A.G., (eds.), A Geologic Time Scale. Cambridge: United Kingdom, Cambridge University Press, 344-383.

Ostermann, D.R., Goodkin, N.F., 2012, New Heavy and Light Stable Isotopic Carbonate Standards for Paleoceanographic Proxy Intercalibrations (abstract), in AGU Ocean Sciences, American Geophysical Union, Salt Lake City, Utah.

Padilla y Sánchez, R.J., 1978, Geología y estratigrafía (Cretácico Superior) del límite suroeste del estado de Nuevo León: Universidad Nacional Autónoma de México, Revista del Instituto de Geología, 2(1), 37-44.

Padilla y Sánchez, R.J., 1985, Estructuras de La Curvatura de Monterrey, Estados de Coahuila, Nuevo León, Zacatecas y San Luis Potosí: Revista del Instituto de Geología, 6, 1-20.

Parente, M., Frijia, G., and Matteo Di Lucia, M. 2007, Carbon-isotope stratigraphy of Cenomanian-Turonian platform carbonates from the southern Apennines (Italy): a chemostratigraphic approach to the problem of correlation between shallow-water and deep-water successions, Journal of the Geological Society, 164, 609-620.

Pessagno, E.A., Martin, C., 2003, Tectonostratigraphic evidence for the origin of the Gulf of Mexico, in Bartolini, C., Buffler, R.T., Blickwede, J., (eds.), The Circum-Gulf of Mexico and the Caribbean: Hydrocarbon Habitats, Basin Formation, and Plate Tectonics: Tulsa, Oklahoma, American Association of Petroleum Geologists Memoir 79, 46-74.
Pindell, J.L., 1985, Alleghenian reconstruction and subsequent evolution of the Gulf of Mexico, Bahamas, and Proto-Caribbean: Tectonics, 4(1), 1-39.

Scholle, P., Arthur, M.A., 1980, Carbon isotopic fluctuations in pelagic limestone: Potential stratigraphic and petroleum exploration tool: American Association of Petroleum Geologists Bulletin, 64 (1), 67-87.

Schouten, S., Hopmans, E.C., Forster, A., van Breugel, Y., Kuypers, M.M.M., Sinninghe Damsté, J.S., 2003, Extremely high sea-surface temperatures at low latitudes during the middle Cretaceous as revealed by archaeal membrane lipids: Geological Society of America, 31(12), 1069-1072.

Selvius, D.B., Wilson, J.L., 1985, Lithostratigraphy and algal-foraminiferal biostratigraphy of the Cupido Formation, Lower Cretaceous, northeast Mexico, in Perkins, B.F., Martin, G.B., (eds.), Habitat of oil and gas in the Gulf Coast: Proceedings of the Fourth Annual Gulf Coast SEPM Foundation, 285-312

Sena, C., 2014, Dolomitization of Lower Cretaceous peritidal carbonates by modified Seawater: Constraints from clumped isotopic paleothermometry, Elemental Chemistry, and Strontium Isotopes: Journal of Sedimentary Research 84(7), 552-566.

Strasser, A., 2007. Astronomical time scale for the Middle Oxfordian to Late Kimmeridgian in the Swiss and French Jura Mountains: Swiss Journal of Geoscience 100, 407-429.

Tardy, M., 1973, Sobre la Tectonica de la Sierra Madre Oriental en el sector de Parras, Coah., el cabalgamiento de la Serie Parrense: Boletín de la Sociedad Geológica Mexicana, 34, 51-70, http://dx.doi.org/10.18268/ BSGM1973v34n1a5

Torres de la Cruz, F., 2011, Caracterización del arrecife Cupido en Puerto México, Nuevo León: Linares, Nuevo León, Mexico, Facultad de Ciencias de la Tierra, Universidad Autónoma de Nuevo León, Bachelor thesis, $122 \mathrm{pp}$.

Torres de la Cruz, F., 2014, Microbialitas de la Formación Cupido en el noreste de México: Linares, Nuevo León, Mexico, Universidad Autónoma de Nuevo León, Facultad de Ciencias de la Tierra, MSc thesis, 118 pp.

Torres de la Cruz, F., Chacón-Baca, E., Gómez-Mancha, Y.E., Cossío-Torres, T., 2018, A palaeobiological window into the Lower Cretaceous Cupido Formation: Puerto México section, Nuevo Leon, Mexico: Carnets de Géologie, 18(8), 187-203.

van Hinsbergen, D.J.J., Groot, L.V. De, Schaik, S.J. Van, 2015, A Paleolatitude Calculator for Paleclimate: Plos One, 10(6), 1-21.

Van Wagoner, J.C., Mitchum, R.M., Campion, K.M., Rahmanian, V.D., 1990, Siliciclastic Sequence Stratigraphy in Well Logs, Cores, and Outcrops: Concepts for High-Resolution Correlation of Time and Facies: Tulsa, Oklahoma, American Association of Petroleum Geologists Methods in Exploration Series, 7, 60 pp.

Wilson, J.L., 1999, Controls on the wandering path of the Cupido reef trend in northeastern Mexico, in Bartolini, C., Wilson, J.L., Lawton, T.F., (eds.) Mesozoic Sedimentary and Tectonic History of North-Central Mexico: Boulder, Colorado, Geological Society of America Special Paper 340 135-143.

Wilson, J.L., Pialli, G., 1977, A Lower Cretaceous shelf margin in northern Mexico, in Bebout, D.G., Loucks, R.G., (eds.), Cretaceous Carbonates of Texas and Mexico: Austin, Texas, Bureau of Economic Geology, Report of Investigations, 89, 286-294.

Wilson, J.L., Ward, W.C., 1993, Early Cretaceous Carbonate Platforms of Northeastern and East-Central Mexico, in Simon, J.A., Scott, R.W., Masse, J.P. (eds.), Cretaceous Carbonate Platforms: American Association of Petroleum Geologists Memoir, 56, 35-50.

Wright, V.P., 1984, Peritidal carbonate facies models: A review, Geol. Journal, 19, 309-325.

Zell, P., Stinnesbeck, W., Hering, F., 2016, A coral-rich unit of Berriasian (Early Cretaceous) age in the Sierra Madre Oriental of northeastern Mexico Journal of South American Earth Sciences, 69, 91-102.

Zwanzinger, J.A., 1978, Geología Regional del Sistema Sedimentario Cupido: Boletín de La Asociación Mexicana de Geólogos Petroleros, 30 (1-2), 3-55.

Manuscript received: december 4, 2018

Corrected manuscript received: august 25, 2019

Manuscript accepted: august 27, 2019 